\title{
Long-term prognostic and predictive factors in hormone receptor positive breast cancer
}

\author{
Helena Fohlin
}

Linköping University

Department of Clinical and Experimental Medicine

SE-581 85 Linköping, Sweden

Linköping 2018 
(C) Helena Fohlin, 2018

Cover illustration: Linda Sjöblom

All previously published papers were reproduced with permission from the publisher. Paper II is an open access article and published under the terms of the Creative Commons Attribution 4.0 International License.

Printed in Sweden by LiU-Tryck, Linköping, Sweden, 2018

ISBN: 978-91-7685-372-6

ISSN: 0345-0082 


\section{Till Linnéa}

Jag genar bland blomstrande snår

och här finns så mycket gott man vill smaka.

Men när de plöjer små färdiga spår,

ja, då får jag lite lust att springa över alltihop och tillbaka

- Lars Winnerbäck 


\section{Table of contents}

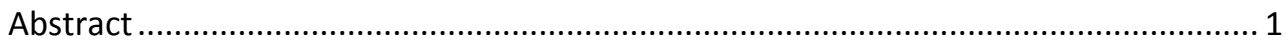

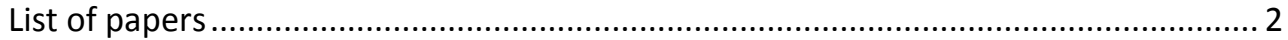

Populärvetenskaplig sammanfattning ……………….......................................... 3

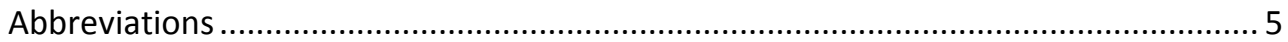

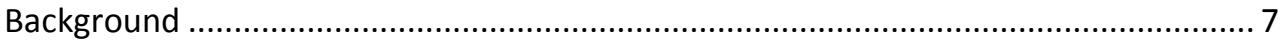

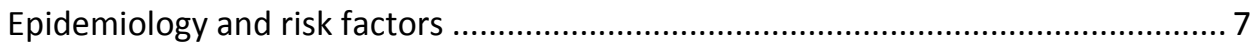

Prognostic and predictive factors..................................................................... 9

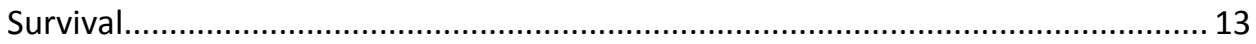

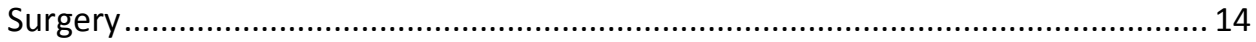

Adjuvant treatment according to the Swedish national management program ..... 14

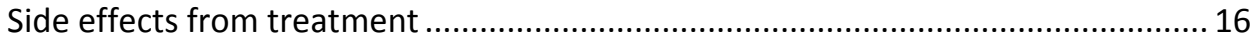

Prognostic gene expression profiles.................................................................... 16

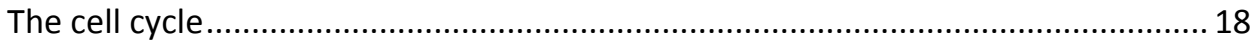

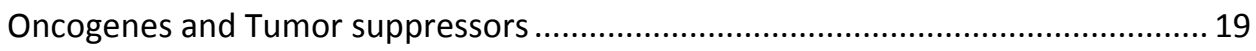

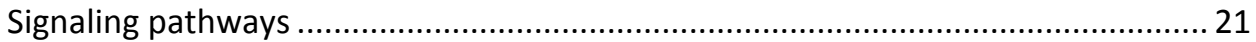

The estrogen receptor (ER) and the progesterone receptor (PR) ......................... 21

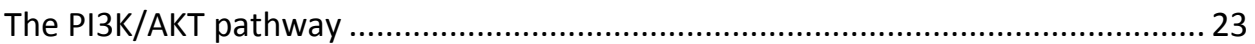

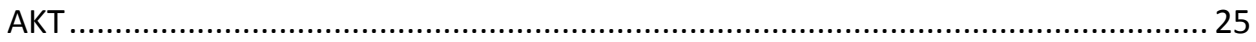

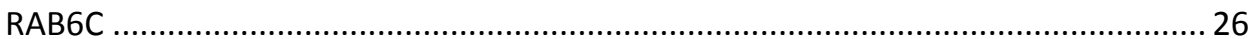



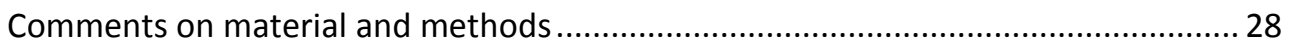



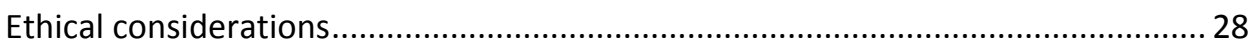

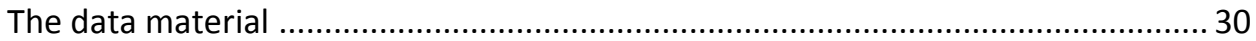

Protein expression determination .................................................................... 30

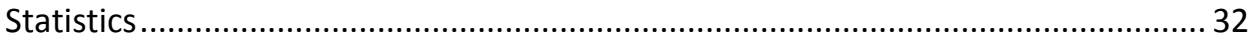






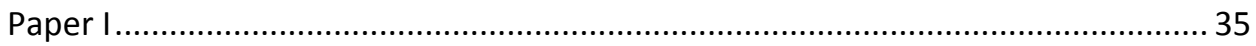

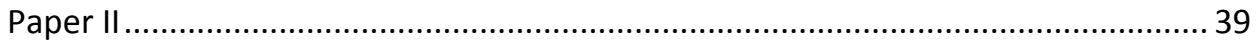

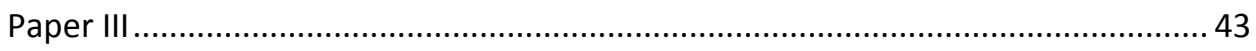

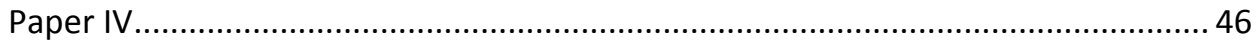

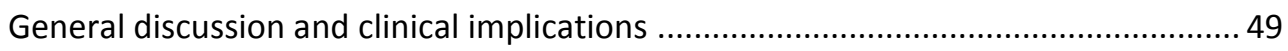



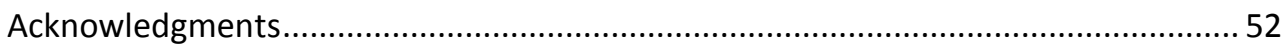

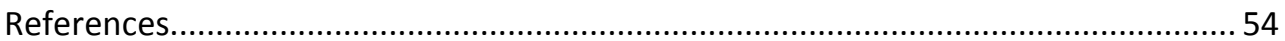





\section{Abstract}

The breast cancer survival in Sweden is good (almost 90 \% 5-year relative survival) and has increased over time. For women with hormone receptor negative tumors, most relapses occur within the first 5 years after diagnosis. Thereafter the recurrence risk decreases rapidly. For women with estrogen receptor positive (ER+) tumors the annual risk for late recurrences is $1-2 \%$, even after 5 years of endocrine therapy. This risk accumulates so that approximately $25 \%$ of the patients that are recurrence-free after five years from diagnosis may experience a relapse within further 15 years of follow-up. The relatively high long-term risk calls for identification of prognostic and predictive markers with long-term effect. Though, the number of such markers with proven significance is limited. Of the clinical characteristics, only nodal status and to some extent tumor size and tumor grade have been shown to have long-term prognostic value. In this thesis, we propose long-term prognostic and predictive markers for breast cancer.

In paper I, we suggest the protein v-akt murine thymoma viral oncogene homologue 2 (AKT2) as a long-term prognostic marker among patients with ER+ tumors. In our study, besides nodal status, AKT2 was the only factor with long-term prognostic value. This is in accordance with some other studies, though we also showed that the significance of AKT2 was limited to ER+ tumors and that the impact increased with higher ER expression.

Approximately $75-85 \%$ of the ER+ tumors are also progesterone receptor positive (PR+). $\mathrm{ER}+$ /progesterone receptor negative (PR-) tumors are considered to be more aggressive and patients with such tumors are often treated with chemotherapy. In this group, more specific subgroups for targeted therapy are needed.

Whereas ER has long been established as a predictive factor regarding tamoxifen benefit, the role of PR has not been clarified to date. In paper II, we showed that PR status adds predictive value to ER considering the long-term benefit from tamoxifen.

In paper III, we aimed to identify new prognostic markers among patients with ER+ tumors. Systemically untreated patients with ER+/PR-tumors and high expression of the Ras-related protein RAB6C (RAB6C) had reduced distant recurrence rate. Therefore, we suggest RAB6C as a candidate marker for subgroup division among patients with ER+/PR- tumors.

According to the results from paper II, there might be subgroups of patients with ER+/PRtumors that do benefit from tamoxifen. The aim of paper IV was to identify such subgroups. Here, we suggest that patients with ER+/PR- tumors and low RAB6C expression do benefit from tamoxifen.

The results from this thesis may encourage further studies for more specific subgroup divisions. Such studies may lead to changes in the management program, where some patients with $\mathrm{ER}+$ tumors should receive prolonged or more intense treatment and others reduced treatment based on the pathological markers AKT2, PR and RAB6C. 


\section{List of papers}

This thesis is based on the following original papers, which are referred to in the text by their Roman numerals.

I. Helena Fohlin, Gizeh Pérez-Tenorio, Tommy Fornander, Lambert Skoog, Bo Nordenskjöld, John Carstensen, Olle Stål. Akt2 expression is associated with good long-term prognosis in estrogen receptor positive breast cancer. Eur J Cancer. 2013 Apr;49(6):1196-204.

II. Anna Nordenskjöld ${ }^{*}$, Helena Fohlin ${ }^{*}$, Tommy Fornander, Britta Löfdahl, Lambert Skoog, Olle Stål. Progesterone receptor positivity is a predictor of long-term benefit from adjuvant tamoxifen treatment of estrogen receptor positive breast cancer. Breast Cancer Res Treat. 2016 Nov;160(2):313-322.

III. Helena Fohlin, Tove Bekkhus, Josefine Bostner, Tommy Fornander, Bo Nordenskjöld, John Carstensen, Olle Stål. RAB6C is an independent prognostic factor in estrogen receptor-positive/progesterone receptornegative breast cancer. Submitted.

IV. Helena Fohlin, Tove Bekkhus, Josefine Bostner, Tommy Fornander, Bo Nordenskjöld, John Carstensen, Olle Stål. Low RAB6C expression predicts tamoxifen benefit in estrogen receptor-positive/progesterone receptornegative breast cancer. Manuscript.

*The authors contributed equally 


\section{Populärvetenskaplig sammanfattning}

\section{Biologiska markörer påverkar långtidsöverlevnad för bröstcancerpatienter}

Bröstcancer är en vanlig sjukdom som drabbar över 8000 kvinnor varje år i Sverige. Samtidigt som allt fler kvinnor insjuknar har överlevnaden förbättrats. Femårsöverlevnaden är nästan 90 \% och tioårsöverlevnaden nära 80 \%. Många patienter lever alltså länge efter diagnos, men återfallen kan komma sent. Hur stor risk en patient har för återfall beror delvis på tumörens egenskaper och påverkan kan vara olika stark på kort respektive lång sikt.

Två av de viktigaste tumöregenskaperna är hormonreceptorerna för östrogen och progesteron. Om tumören är östrogenreceptorpositiv (ER+) eller progesteronreceptorpositiv (PR+) betyder det att cancercellerna har receptorer för östrogen respektive progesteron. Receptorerna kan ta upp signaler från dessa hormoner och stimulera cellerna att växa. För kvinnor med tumörer som saknar dessa receptorer inträffar de flesta återfallen inom fem år efter diagnos. Därefter sjunker återfallsrisken kraftigt. Men de flesta tumörerna är ER+ och i dessa fall har patienterna nytta av antihormonell behandling. Denna behandling kan antingen sänka hormonhalterna eller blockera hormonreceptorerna så att cancercellerna får svårare att överleva. På kort sikt är prognosen god, men trots behandling kommer i snitt var fjärde patient som efter fem år från diagnos lever utan tecken på återfall att få det inom ytterligare 15 år.

Trots den relativt höga långtidsrisken är det ont om markörer med bevisad effekt för att kunna särskilja patientgrupper med olika god prognos på lång sikt. Sådana långtidsmarkörer skulle kunna bidra till att identifiera patienter som har nytta av förlängd behandling respektive patienter som kan slippa onödig behandling. Några tidigare studier har indikerat att patienter har bra prognos på lång sikt om det i 
cancercellerna finns mycket av ett protein som heter AKT2. Vår studie har visat samma resultat, men vi har också sett att det är begränsat till ER+ tumörer och att betydelsen av AKT2 ökade ju fler östrogenreceptorer tumören har.

Cirka tre av fyra ER+ tumörer är också PR+. Våra resultat har visat att patienter som har tumörer som är både ER+ och PR+ på lång sikt har större nytta av antihormonell behandling jämfört med tumörer som har östrogenreceptorer, men saknar progesteronreceptorer (ER+/PR-). Den senare tumörgruppen anses mer aggressiv och patienterna ges ofta tilläggsbehandling i form av cellgifter, som kan ge svåra biverkningar som följd. I denna patientgrupp är det betydelsefullt att identifiera fler undergrupper för att kunna ge mer målriktad och skonsammare behandling. I våra studier har vi sett att patienter med ER+/PR- tumörer och som varken har fått cellgifter eller antihormonell behandling har bättre prognos om cellerna innehåller mycket av proteinet RAB6C. När vi vidare undersökte om det finns undergrupper bland patienter med ER+/PR- tumörer som har större nytta av antihormonell behandling, gällde detta för tumörer som innehåller mindre mängd RAB6C.

Även om det behövs ytterligare studier för att bekräfta resultaten, kan de i framtiden ha betydelse inom praktisk sjukvård. Patienter som har god överlevnadchans även med minskad behandling bör informeras om nyttan respektive riskerna med behandling, medan andra möjligtvis ska rekommenderas mer intensiv eller förlängd behandling. 


\section{Abbreviations}

\begin{tabular}{|c|c|}
\hline AKT & v-akt murine thymoma viral oncogene homologue \\
\hline AP-1 & activator protein 1 \\
\hline BCS & breast conserving surgery \\
\hline BRCA & breast cancer gene \\
\hline $\mathrm{CISH}$ & chromogenic in situ hybridization \\
\hline CMF & cyclophosphamide, methotrexate and fluorouracil \\
\hline EBCTCG & Early breast cancer trialists' collaborative group \\
\hline EGF & epidermal growth factor \\
\hline EGFR & epidermal growth factor receptor \\
\hline EIA & enzyme immunoassay \\
\hline ER & estrogen receptor \\
\hline ESR & estrogen recptor gene \\
\hline FEC & fluorouracil, epirubicin, cyclophosphamide \\
\hline FFPE & formalin-fixed, paraffin-embedded \\
\hline FGFR & fibroblast growth factor receptor \\
\hline $\mathrm{FISH}$ & fluorescence in situ hybridization \\
\hline G1 phase & first gap phase \\
\hline GDP & guanosine diphosphate \\
\hline GTP & guanosine triphosphate \\
\hline GPCR & G-protein-coupled recptors \\
\hline HER2 & human epidermal growth factor receptor 2 \\
\hline HOXB13 & homeobox B13 \\
\hline IF & isoelectric focusing \\
\hline IGF1R & insulin like growth factor 1 receptor \\
\hline IL17BR & interleukin 17 receptor $B$ \\
\hline $\mathrm{HR}$ & hazard ratio \\
\hline IGF & insulin-like growth factor \\
\hline $\mathrm{IHC}$ & immunohistochemical staining \\
\hline IQR & interquartile range \\
\hline Ki-67 & marker of proliferation Ki-67 \\
\hline M & presence of distant metastasis \\
\hline M phase & mitotic phase \\
\hline MAP & mitogen-activated protein \\
\hline mTOR & mammalian target of rapamycin \\
\hline mTORC2 & mammalian target of rapamycin complex 2 \\
\hline $\mathrm{N}$ & degree of spread to the regional lymph nodes \\
\hline NCBI & National center for biotechnology information \\
\hline$N F-\kappa B$ & nuclear factor kappa-light-chain-enhancer of activated B cells \\
\hline NHG & Nottingham histological grade \\
\hline
\end{tabular}




$\begin{array}{ll}\text { p53 } & \text { tumor protein p53 } \\ \text { PAKT } & \text { phosphorylated AKT } \\ \text { PDK-1 } & \text { phosphoinositide dependent kinase 1 } \\ \text { PI3K } & \text { phosphatidylinositol-3-kinase } \\ \text { PIK3CA } & \text { phosphatidylinositol 3-kinase catalytic subunit alpha } \\ \text { PIP } 3 & \text { 3'-phosphorylated phosphoinositide } \\ \text { PR } & \text { progesterone receptor } \\ \text { PTEN } & \text { phosphatase and tensin homolog } \\ \text { RAB6C } & \text { RAB6C, member RAS oncogene family } \\ \text { RPS6K1 } & \text { ribosomal protein S6 kinase 1 } \\ \text { RT } & \text { radiotherapy } \\ \text { RTK } & \text { receptor tyrosine kinase } \\ \text { S phase } & \text { synthetic phase } \\ \text { SISH } & \text { silver enhanced in situ hybridization } \\ \text { SNP } & \text { single-nucleotide polymorphism } \\ \text { SP-1 } & \text { specificity protein 1 } \\ \text { STAT3 } & \text { signal transducer and activator of transcription } 3 \\ \text { STEPP } & \text { subpopulation treatment effect pattern plot } \\ \text { T } & \text { size of the primary tumor } \\ \text { TAM } & \text { tamoxifen }\end{array}$




\section{Background}

\section{Epidemiology and risk factors}

Breast cancer is the most common cancer among women worldwide [1]. In Sweden, the risk for a woman to develop the disease before the age of 75 is $11 \%$ [2]. It represents $30 \%$ of all female cancer, but only $13 \%$ of the cancer deaths, reflecting the good prognosis [3]. The median age for being diagnosed with breast cancer is 65 and $17 \%$ are younger than 50 years old (Swedish Cancer Registry). Specific genetic mutations are strong risk factors for developing breast cancer, often at younger age compared to sporadic cancer [4]. Such germline mutations account for $5-10 \%$ of all breast cancers, where the most well-known are BRCA1 and BRCA2 [5]. Another strong risk factor is detection of high density breast tissue [6]. Many other established risk factors are hormonally related. Early menarche, late menopause and short menstrual cycles increase the risk, as well as use of exogenous hormones (oral contraceptive pill and combined postmenopausal hormone replacement therapy) , whereas younger age at giving birth to the first child, going through many full-time pregnancies and breastfeeding are protecting factors [7-12]. In some cases, the risk factors differ depending on age. Obesity implies higher risk among postmenopausal, but is a protecting factor among premenopausal women [13]. Other potentially preventable factors include radiation exposure, high alcohol consumption and lack of physical activity [14].

Even adjusting for the fact that the population is getting older, the incidence of breast cancer has increased during the last decades (Fig. 1). One reason for that is probably that women are getting pregnant later in life and having fewer children [15]. Another contributing factor may be that women in certain periods were offered hormone replacement therapy due to menopause symptoms to a larger extent [10- 
$12,14,16,17]$. In general, an increase in a specific disease does not always reflect true incidence increase, but can be due to improved detecting methods. In the late 80 's the breast cancer incidence in Sweden increased as mammography screening was introduced [18]. This leads to earlier detection and improved survival $[19,20]$. Another way to analyze survival differences over time is to observe mortality rates according to the Swedish cause of death register. Also from that point of view, the breast cancer mortality has decreased (Fig. 1).

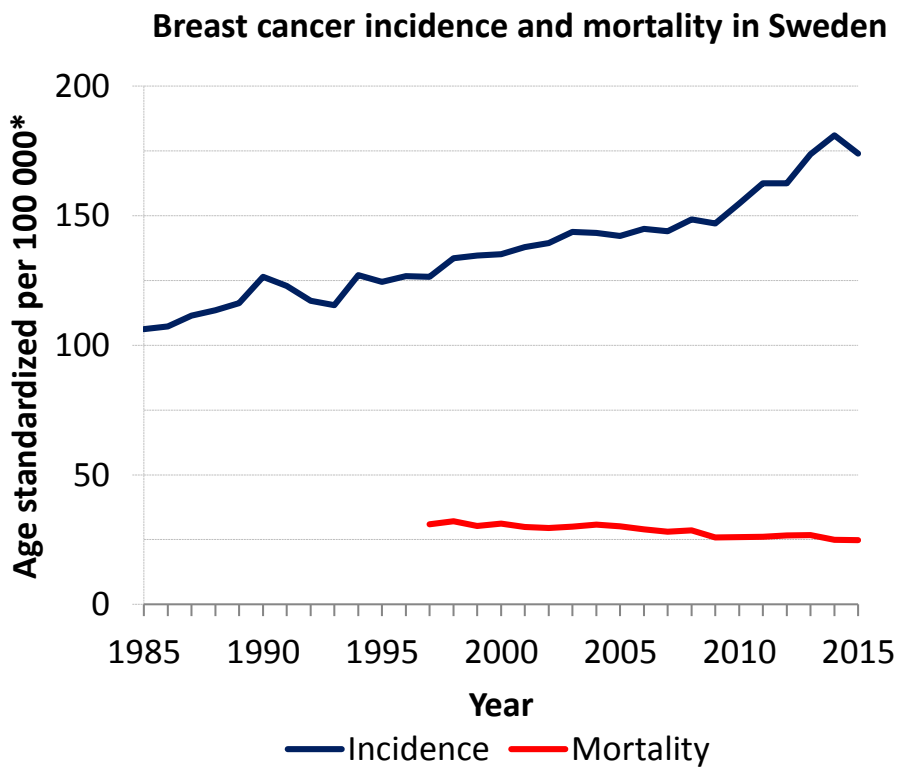

*using the 2000 Sweden standard population

Fig. 1 Breast cancer incidence and mortality in Sweden, based on data from the National Board of Health and Welfare (Socialstyrelsen) [3]. 


\section{Prognostic and predictive factors}

Prognostic factors describe the clinical outcome for the patients without treatment, in contrast to predictive factors which reflect the chance that the patients will respond to a specific treatment. The most important prognostic factors are the stage of the tumor (TNM), Nottingham histological grade (NHG), Ki-67 and age. Predictive factors include the estrogen receptor (ER), the progesterone receptor (PR) and the human epidermal growth factor receptor 2 (HER2). Some biomarkers are considered to be both prognostic and predictive, for example ER and HER2 [21].

\section{Stage (TNM)}

The stage is determined by the tumor size $(T)$, lymph nodal involvement $(N)$ and presence/absence of distant metastasis $(M)$, and is the most significant prognostic factor. Stage I include small tumors with no lymph nodal involvement (NO), whereas stage II and stage III include larger tumors and/or lymph nodal involvement. In presence of distant metastasis (M1), the disease is classified as stage IV, independently of T and N. Most patients are diagnosed with stage I or stage II disease and have good survival.

\section{Nottingham histologic grade (NHG)}

NHG represents the aggressive potential of the tumor and is determined by three different components: tubular differentiation (how well the tumor cells try to recreate normal glands), pleomorphism (how ugly the tumor cells look) and mitosis (how much the tumor cells are dividing). Each of these features is scored and added to a final score which is used to assess the tumor grade 1, 2 or 3 representing low, intermediate or high. 


\section{Ki-67}

The nuclear protein Ki-67 is a proliferation marker which is determined by how fast the cells are dividing. The more tumor cells that are positive for Ki-67, the more rapidly the tumor tissue is forming new cells. Ki-67 is associated with tumor grade (NHG) and high Ki-67 confers poorer prognosis [22-24].

\section{Age}

Younger women ( $<35$ years old) at the time of diagnosis have higher risk of dying from the disease compared with middle-aged counterparts, partly because young age is associated with later stage and more aggressive tumor types [25, 26]. Women older than 70 years old also have lower 5 -year relative survival compared with middle-aged patients. Here, a contributing factor may be that elder women are receiving less aggressive treatment [27].

\section{The estrogen receptor (ER) and the progesterone receptor (PR)}

Approximately $80 \%$ of the breast cancer tumors are estrogen receptor positive (ER+) and out of these are $75-85 \%$ also progesterone receptor positive (PR+). In the 1980's ER and PR were suggested as predictive factors for endocrine treatment [2830]. Endocrine treatment includes tamoxifen, which acts in a way that blocks the hormone receptors and aromatase inhibitors which lower the hormone levels. Hormone receptor positivity is associated with good 5-year relative survival. However, despite endocrine treatment, the annual long-term risk for breast cancer recurrence is higher than for patients with hormone receptor negative tumors (Fig. 2). 


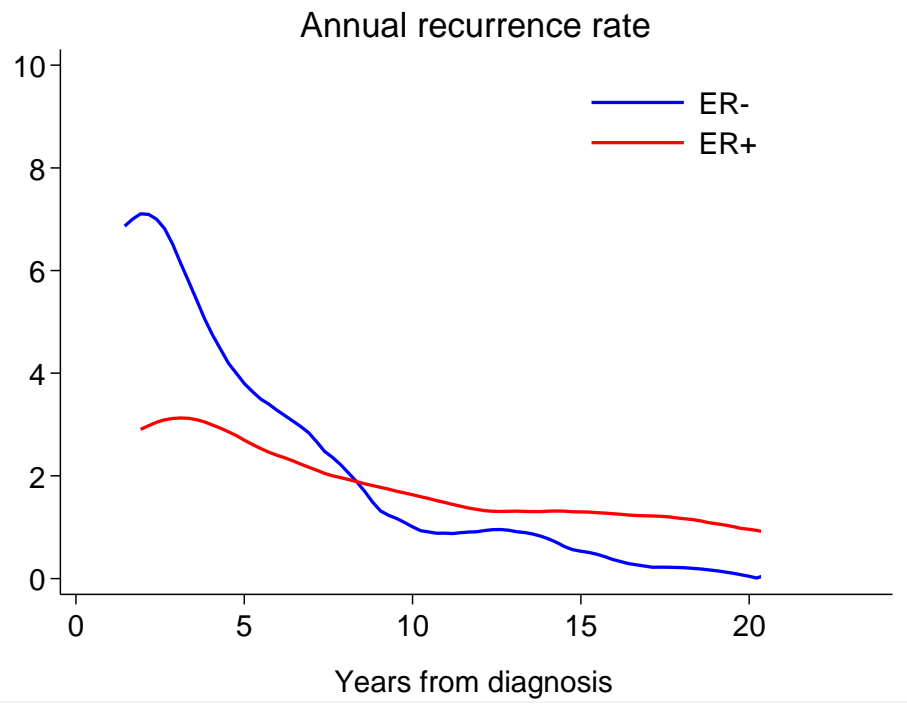

Fig. 2 Annual recurrence rate per 100 person years at risk divided by ER status. The figure is based on data from Paper II - IV.

\section{The human epithelial receptor $\mathbf{2}$ gene (HER2)}

HER2 is amplified in approximately $15 \%$ of the breast cancer cases and associated with more aggressive clinical behavior. The gene encodes a transmembrane tyrosine kinase growth factor receptor which acts through a variety of pathways, including the mitogen-activated protein (MAP) kinase and PI3K/AKT pathways. Enhanced activity in these pathways eventuate proliferation, angiogenesis, altered cell-cell interaction, increased cell motility, metastases and resistance to apoptosis [31]. In the 2000's, HER2 was identified as a target gene for response to trastuzumab, an antibody binding to the receptor [32-34]. This therapy significantly improved the disease-free survival for patients with HER2 amplified breast cancer [32, 35, 36]. 


\section{Subtypes}

Breast cancer may be divided into different treatment groups based on the routinely evaluated pathological markers described above. More recently, molecular profiling methods have been used to define clinical relevant molecular subtypes: luminal Alike, luminal B-like, HER2 subtype, and basal-like [37-39]. These subtypes can essentially be categorized into the pathological subtypes using ER, PR, Ki-67 and HER2 [40]. 


\section{Survival}

The breast cancer survival in Sweden is good (almost 90 \% 5-year relative survival) and has increased over time [26, 41, 42]. For women with hormone receptor negative tumors, most relapses occur within the first 5 years after diagnosis. Thereafter the recurrence risk decreases rapidly. For women with hormone receptor positive tumors the cumulative 15-year risk for recurrences is $30 \%$, even after 5 years of tamoxifen $[43,44]$. A recent meta-analysis including patients with ER+tumors showed that the risk of distant recurrence after five years of endocrine therapy with 20-years of follow-up was up to $41 \%$ [45]. This shows the importance of identifying prognostic and predictive markers with long-term effect on survival. At present, the number of such markers with proven long-term significance is limited. Among the clinical characteristics, only nodal status and to some extent tumor size and tumor grade have been shown to have long-term prognostic value $[45,46]$. Table 1 shows the relative survival for breast cancer patients in two Swedish health care regions divided by stage at diagnosis.

Table 1 Stage distribution and age-standardized relative survival for patients diagnosed with breast cancer between 2004 and 2008 in the Western and South-East health care regions in Sweden.

\begin{tabular}{|c|c|c|c|c|}
\hline Stage & & $\begin{array}{r}\text { Breast cancer } \\
\text { patients (\%) } \\
\end{array}$ & $\begin{array}{r}\text {-year relative } \\
\text { survival (\%) } \\
\end{array}$ & $\begin{array}{r}10 \text {-year relative } \\
\text { survival (\%) } \\
\end{array}$ \\
\hline I & $\mathrm{T}<20 \mathrm{~mm}, \mathrm{NO}, \mathrm{MO}$ & 45 & 97 & 91 \\
\hline II & $\begin{array}{l}\mathrm{T} 20-50 \mathrm{~mm}, \mathrm{~N} 0-3, \mathrm{MO} \text { or } \\
\mathrm{T}<20 \mathrm{~mm}, \mathrm{~N} \geq 1, \mathrm{MO} \text { or } \\
\mathrm{T}>50 \mathrm{~mm}, \mathrm{NO}, \mathrm{MO}\end{array}$ & 40 & 87 & 77 \\
\hline III & $\begin{array}{l}\mathrm{T} 20-50 \mathrm{~mm}, \mathrm{~N} \geq 4, \mathrm{M} 0 \text { or } \\
\mathrm{T}>50 \mathrm{~mm}, \mathrm{~N} 1-3, \mathrm{M} 0\end{array}$ & 12 & 65 & 46 \\
\hline IV & Any $\mathrm{T}$, any N, M1 & 3 & 20 & 11 \\
\hline Total & & 100 & 86 & 76 \\
\hline
\end{tabular}




\section{Surgery}

\section{Breast surgery}

Nowadays, most patients are operated with breast-conserving surgery (BCS). The proportion of BCS compared with mastectomy has increased due to smaller tumor size, partly because of mammography screening. For unifocal tumors, it has been shown that the survival rate for BCS combined with radiotherapy against the breast is similar with that of mastectomy [47-49].

\section{Axillary surgery}

The main purpose of axillary surgery is tumor staging, in order to provide guidance for further adjuvant treatment. Node status is mostly determined by sentinel-node biopsy. If the sentinel node is positive, axillary dissection is performed.

Earlier, axillary dissection was the standard technique, but the introduction of sentinel-node biopsy has changed the approach as the status of the axilla can be established with less morbidity for patients when compared with complete axillary dissection.

\section{Adjuvant treatment according to the Swedish national management program}

\section{Endocrine therapy}

Generally, patients with hormone receptor positive breast cancer receive endocrine therapy. If the tumor is small $(\leq 10 \mathrm{~mm}$ ), lymph node negative and luminal A (strong $E R+$ and PR+, low proliferation and HER2-) abstaining of endocrine therapy may be 
considered. Premenopausal women with intermediate or high risk are recommended tamoxifen for at least five years. For postmenopausal women the primary choice of endocrine treatment is aromatase inhibitors.

\section{Chemotherapy}

Chemotherapy is standard treatment for patients who have axillary node positive breast cancer as well as axillary node negative with other risk factors. Patients with hormone receptor negative breast cancer normally also receive chemotherapy. It is mostly given in a combined treatment of FEC (FEC comes from the initials of the drugs used: fluorouracil, epirubicin, cyclophosphamide) followed by taxane based chemotherapy.

\section{Radiotherapy}

Radiotherapy (RT) against the breast is standard therapy for patients operated with breast conserving surgery. For radical mastectomated patients no RT against the breast is given unless the tumor is larger than $50 \mathrm{~mm}$.

RT against the axilla is not recommended if there are no lymph node metastases. Though, it is standard treatment if there is at least one macro metastasis. If the tumor is of grade 1 and there is only one macro metastasis, no RT may be considered. If only one micro metastasis is found, RT against the axilla or chest wall is normally not provided unless the tumor is larger than $50 \mathrm{~mm}$.

\section{Targeted therapy}

Treatment for one year with trastuzumab together with chemotherapy (taxane) is recommended for patients with HER2+ breast cancer. The HER2 positivity should be 
confirmed by strong immunohistochemical expression (IHC $3+$ ) or FISH/CISH/SISH positivity.

\section{Side effects from treatment}

Endocrine therapy may worsen symptoms from lower levels of estrogen and may cause hot flashes, sweats, dry mucous membranes and musculoskeletal pain [50].

Side-effects from chemotherapy include fatigue, nausea and vomiting, hair loss and also potentially life-threatening effects such as neutropenia [51].

Radiotherapy is associated with radiation fibrosis and damage to the skin [52] and targeted therapy is mainly associated with dermatological side-effects. [53]

\section{Prognostic gene expression profiles}

Several studies are concerned with evaluating the patient's individual risk of recurrence by combining expression profiles of cancer-related genes. One of the first genomic assays developed for this purpose was MammaPrint, which combines the gene expression of 70 genes [54]. It requires freshly frozen tissue collected into an RNA preservative solution, which makes it more complex to conduct than other panels [55]. Although MammaPrint has been shown to have prognostic significance, it performs best as a predictor of distant metastasis during the first 5 years after treatment.

PAM50 is another genomic assay generated from the expression of 50 genes. It has recently been included in recommendations for decisions on adjuvant systemic 
treatment for patients with negative lymph nodal status, hormone receptor positive and HER2 negative disease [56-58].

With Oncotype DX, the expression of five reference genes and 16 cancer-related genes is used [59]. A mathematical computation of the weighted expression of each gene results in a recurrence score which may be divided into three categories with low, intermediate and high risk [55]. $\mathrm{BCl}$ is another algorithmic gene expressionbased signature which also divides the patients into three groups, but involving fewer genes [60]. The algorithm is based on the gene expression ratio of HOXB13 and IL17BR combined with the additive expression values of five cell-cycle genes. It has been shown to provide significant prognostic value for patients with ER+ and lymph node negative disease.

PAM50, Oncotype DX and $\mathrm{BCl}$ are all performed with RNA from formalin-fixed, paraffin-embedded (FFPE) samples.

There are also other genomic assays which have been shown to have long-term predictive significance for early-stage breast cancer, but none of them was specifically developed for predicting late recurrence [46, 60-62].

Several genomic predictors are already, or will be, part of routine clinical practice in the future $[55,63]$. Even though they have been shown to add predictive significance for early-stage breast cancer, there are some limitations. The cut-off for gene panels varies between studies, making it difficult to identify correct cut-off points for clinical utility. Other issues associated with some gene panels are technical complexity or how to deal with patients identified with intermediate risk. The accuracy in predicting late recurrence in ER+ breast cancer is another issue to be solved. 


\section{The cell cycle}

The purpose of the cell cycle is to accurately duplicate the DNA in the cell and physically split into two daughter cells. This is done in two major steps, the interphase and the mitotic (M) phase. The interphase involves three steps, the first gap (G1) phase, the synthetic (S) phase and the second gap (G2) phase. During the G1 phase, the cell grows physically larger, copies organelles, and makes molecular building blocks that are needed in later steps. During the $S$ phase, the cell synthesizes a complete copy of the DNA in its nucleus and duplicates the centrosome. In the G2 phase, the cell grows more, makes proteins and organelles, and begins to reorganize its contents in preparation for mitosis. In the $\mathrm{M}$ phase, including mitosis and cytokinesis, the cell separates its DNA into two sets and divides its cytoplasm, forming two new cells.

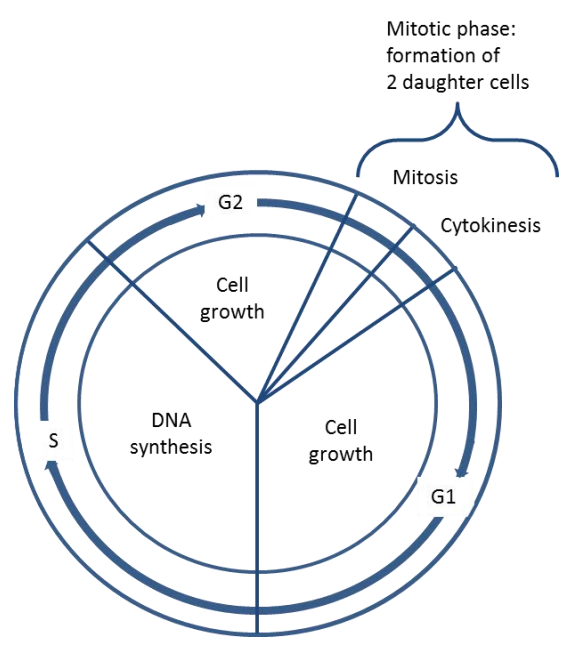

Fig. 3 The cell cycle

Cancer cells behave differently than normal cells in the body. Many of these differences are related to cell division behavior. In contrast to normal cells, cancer cells may make their own growth factors, have growth factor pathways that are 
always active or induce neighboring cells to produce growth factors to sustain them [64]. Cancer cells can also divide many more times than a normal cell and may ignore signals to stop dividing. Other hallmarks of cancer include resisting cell death, inducing angiogenesis, and activating invasion and metastasis $[64,65]$.

\section{Oncogenes and Tumor suppressors}

There are broadly two types of genes involved in tumor initiation and development of cancer: oncogenes and tumor suppressors. Many genes in these categories are involved in the regulation of cell division, cell death, DNA damage and repair. Whereas increased activity of oncogenes may induce cancer, tumor suppressors operate to reduce the likelihood of cancer. In many cancers, there is either a gain of function of oncogenes or loss of function of tumor suppressors which may induce the cell to go through multiple cell divisions and accumulate genetic defects.

\section{Oncogenes}

The normal form of an oncogene, that is not yet mutated, is called proto-oncogene. Several types of mutations may cause increased activity of the proto-oncogenes and turn them into oncogenes. This includes amplification, where a gene gains extra copies and starts producing too much of the protein that the gene is coding for. Other mutations change the amino acid sequence of the protein, which alters its shape and trapping it in a state where it is always active. In other cases, a proto-oncogene may attach to a part of a different gene (chromosomal translocation), whereby a new fusion gene is transcribed into a protein with dysregulated activity [31].

Many of the proteins that transmit growth factor signals are encoded by protooncogenes. Normally, these proteins drive cell cycle progression only when growth 
factors are available. However, if one of the proteins becomes overactive due to mutation, it may transmit signals even when no growth factor is around. In breast cancer, HER2 is a well-known oncogene due to gene amplification.

\section{Tumor suppressors}

Tumor suppressors are negative regulators of cell cycle progression. If they are not working properly, they may not sense signals of DNA damage or trigger a response. DNA methylation, which means that a methyl group is added to the DNA molecule, may change the activity of a gene without changing the DNA sequence. It is a common reason for silencing tumor suppressor genes. Two of four bases in the DNA, cytosine and adenine, can be methylated. Cytosine pairs with guanosin in CpG dinucleotieds and regions with high frequency of CpG sites, so-called CpG islands, are common in promoter regions. Methylation can inhibit genes to be transcribed, either because transcription factors are impeded to bind to DNA, or that a protein complex which binds to the methyl groups alters the structure of histone proteins [66].

One of the most frequently mutated genes in cancer is the tumor suppressor $\mathrm{p} 53$, which controls the $\mathrm{G} 1$ to $\mathrm{S}$ transition. Cancer cells without p53 mutations likely inactivate p53 through other mechanisms [67].

If DNA damage occurs, a functional p53 acts in several ways. First, it blocks the cell cycle progression, gaining time to repair the damage. Secondly, it activates enzymes that may repair the damage. If this is successful the cell cycle may continue, otherwise p53 triggers apoptosis (programmed cell death) so that damaged DNA is not passed on $[4,68]$. When p53 is defective, a cell with damaged DNA may proceed 
with cell division. The daughter cells of such a division are likely to inherit mutations due to the unrepaired DNA of the mother cell.

RAB6C which was studied in paper III and IV in this thesis has been suggested as a tumor suppressor and is regulated by $\mathrm{p} 53[69,70]$.

\section{Signaling pathways}

A signaling pathway is a group of proteins that work together to control cell functions, such as protein synthesis, cell division or cell death. A receptor receives a signal, like a hormone or growth factor, and passes this signal through the membrane onto other proteins, often due to phosphorylation. This means that a phosphate group is added to an amino acid of the next protein, which activates or inactivates the protein. The process is repeated until the last protein in the pathway is activated and the cell function is carried out. Abnormal activation of signaling pathways may lead to cancer. Therefore, drugs are being developed to block specific pathways.

\section{The estrogen receptor (ER) and the progesterone receptor (PR)}

Estrogen affects growth, differentiation and function of the mammary gland and mediates its effects by binding to its receptor, ER [71]. ERs are widely expressed in different tissue types, e.g. in the endometrium, breast, ovarium and hypothalamus and belongs to the family of nuclear receptors, which are ligand-regulated transcription factors, activated by steroid hormones [72]. Two separate genes, ESR1 and ESR2, encode the estrogen receptors ER $\alpha$ and ER $[73]$. In this thesis, ER always refers to $E R \alpha$. 
Unlike most intercellular messengers, the ligands can cross the plasma membrane and directly interact with nuclear receptors inside the cell. In the absence of hormone, estrogen receptors are largely located in the cytosol. Hormone binding to the receptor triggers a number of events. The receptor migrates from the cytosol into the nucleus, pairs up with another receptor, forming a receptor dimer binding to specific sequences of DNA. Once activated, nuclear receptors directly regulate transcription of genes that control a wide variety of biological processes, including cell proliferation, development, metabolism, and reproduction [72, 74]. Besides direct binding to the DNA, ER may change various gene transcriptions indirectly, by binding to other transcription factors, such as AP-1, SP-1, STAT3, or NF- KB [75-77]. Besides these so-called genomic mechanisms, ER may activate signal transduction pathways in the cytoplasm (non-genomic mechanism) $[75,78]$.

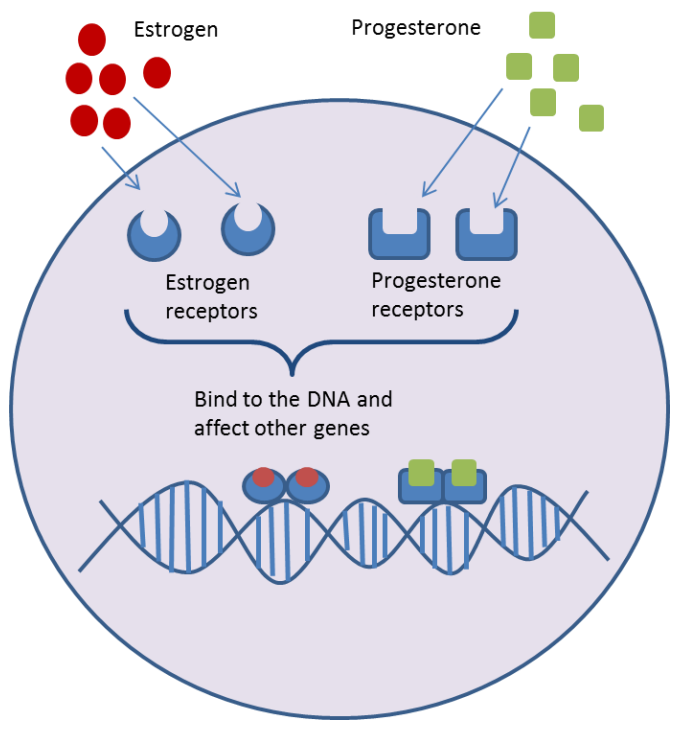

Fig. 4 The classical ER and PR signaling pathway

Approximately 75 - $85 \%$ of the breast tumors have an overexpression of ER, i.e. are producing too much of this protein. They are classified as ER+, and of these, $75-85 \%$ 
are also PR+ [79]. If the tumor is PR+ it indicates an intact ER signaling pathway [80]. But absence of PR may have other reasons than a nonfunctional ER signaling pathway [81]. Growth factors in the insulin-like growth factor (IGF) and epidermal growth factor (EGF) families that activate the PI3K-AKT-mTOR pathway can decrease PR transcription even as they activate other ER functions [82, 83]. Several studies have shown that ER+/PR- tumors have higher levels of epidermal growth factor receptor (EGFR) and HER2 than ER+/PR+ tumors [82, 84, 85].

Tumors that are neither overexpressing ER nor PR (ER-/PR-) represent 10 - $20 \%$ of the breast tumors and only a few percentages are classified as ER-/PR+. Tumors in the latter group are often claimed to be falsely classified as it is stated that PR may not be expressed in absence of ER. The presence of the subgroups differs among different age groups. Women younger than 40 years old are more often diagnosed with an ER-/PR-tumor and presence of ER+/PR-tumors is more common in the ages $55-65[86-88]$.

\section{The PI3K/AKT pathway}

The phosphatidylinositol 3-kinase (PI3K) pathway is the most frequently mutated pathway in breast cancer. In over $70 \%$ of the breast cancer cases there are mutations or gene copy number aberrations of the involved genes, e.g., HER2, PTEN, PIK3CA, IGF1R, FGFR1, RPS6K1, AKT1, AKT2 and EGFR [89]. Alterations in the pathway lead to changes of proteins which regulate cell cycle progression, cell proliferation and cell survival. Further, in ER+ breast cancer cells, PI3K activation promotes estrogendependent and -independent ER transcriptional activity, which, in turn, may contribute to anti-estrogen resistance $[89,90]$.

The PI3K/AKT pathway is activated by growth factor receptor tyrosine kinases (RTKs) and G-protein-coupled receptors (GPCRs). RTKs, for example HER2 and fibroblast 
growth factor receptor (FGFR) 1, are enzymes that transfer phosphate groups to the amino acid tyrosine which hereby can transmit signals to other molecules in the cell. GPCRs are a family of cell surface receptors that transmit signals inside the cell through so called $\mathrm{G}$ proteins. G proteins bind the nucleotide guanosine triphosphate (GTP) and break it down to guanosine diphosphate (GDP), whereby phosphate is released and may activate signaling pathways. RTKs and GPCRs can recruit PI3K to the cell surface receptors, which results in production of 3'-phosphorylated phosphoinositide $\mathrm{PIP}_{3}$. This further helps AKT to recruit to the membrane, where it is phophorylated by phosphoinositide dependent kinase 1 (PDK-1) and mammalian target of rapamycin complex 2 (mTORC2) [91-94].

In turn, AKT can activate several proteins that regulate protein synthesis, cell proliferation and survival. PTEN acts as a negative regulator of the pathway by dephosphorylating $\mathrm{PIP}_{3}$.

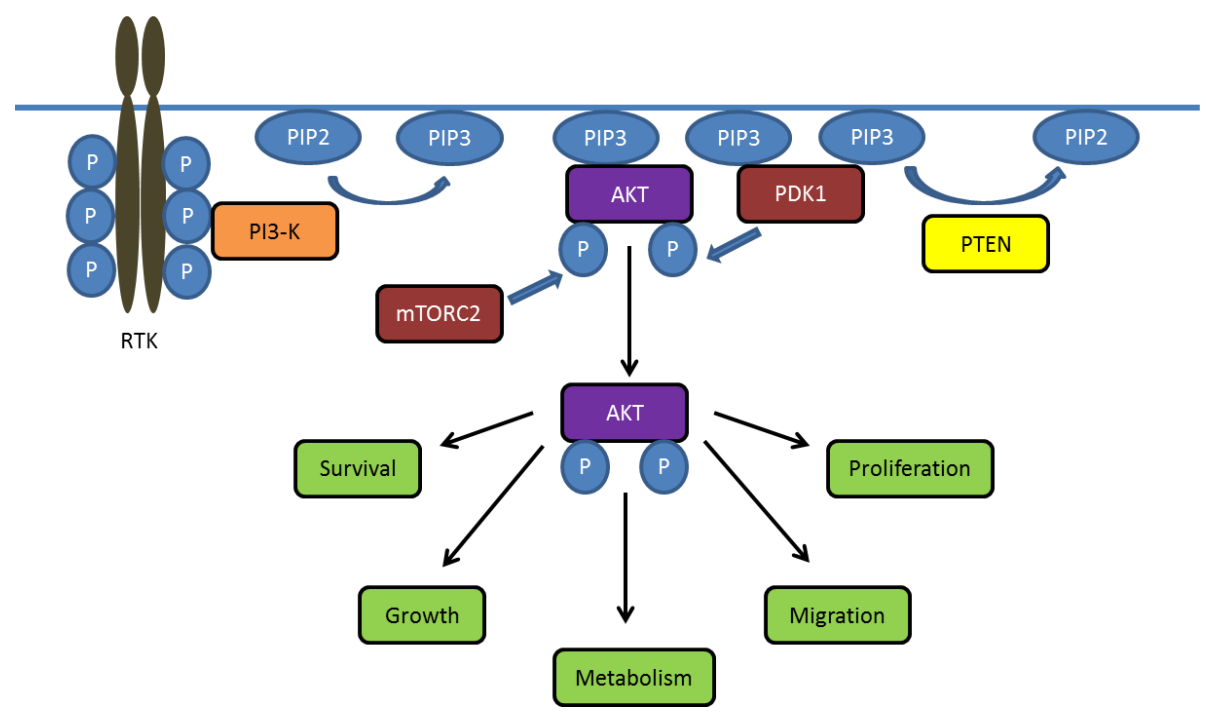

Fig. 5 The PI3K/mTOR pathway 


\section{AKT}

AKT (also known as PKB) was first isolated in the 1970s from the transforming murine retrovirus AKT8 discovered in an AKR mouse thymoma cell line [95]. The human AKT1 and $A K T 2$ genes could be cloned 10 years later, followed by a third AKT gene, AKT3 in $1999[96,97]$. The genes are located at different chromosomal locations, AKT1 at $14 q 32, A K T 2$ at $19 q 13$ and $A K T 3$ at $1 q 44$. The corresponding proteins show high homology, where AKT1 and AKT3 are most similar (83 \%), followed by AKT1 and AKT2 (82\%) and AKT2 and AKT3 (77\%) [98]. Despite the similar structural domains, the proteins seem to have different functions. Studies of mammary tumors in mouse models have shown that whereas AKT1 plays an important role in tumor initiation, AKT2 is mainly involved in the metastatic process $[99,100]$. AKT3 has been suggested to be involved in triple negative breast cancer, where targeting of AKT3 inhibited growth of triple-negative breast cancer cells in mouse models [98, 101]. Activating mutations in AKT1 are found in $2 \%$ of all breast cancer tumors and belongs to the 20 most commonly mutated genes [102]. 


\section{RAB6C}

Rab-GTPases are members of the RAS family and their expression product can bind to GTP $[69,70,103]$. They are involved in regulating intracellular protein trafficking pathways and hypothesized to have altered expression levels in certain cancer [69] . One of five ancestral RAB genes is RAB6, which is conserved from yeast to humans. Gene duplication and alternative splicing during evolution has resulted in different $R A B 6$ isoforms in humans. $R A B 6 A$ and the spliced variant $R A B 6 A^{\prime}$ are located on chromosome $11, R A B 6 B$ which is a gene duplication of $R A B 6 A / A^{\prime}$ on chromosome 3 and $R A B 6 C$ (also known as WTH3) on chromosome 2. The RAB6C gene consists of a single exon and shares highest identity with the $R A B 6 A^{\prime}$ transcript. Therefore, it is suggested that $R A B 6 C$ has been generated by retrotransposition of a fully processed $R A B 6 A^{\prime}$ mRNA, but encoding a functional protein with altered characteristics compared to RAB6A'.

Unlike other RAB6s, which are located in the Golgi apparatus, RAB6C is primarily distributed in the cytoplasm and in the nucleus [104]. The protein is involved in regulation of centrosome duplication and cell cycle progression [69]. As the RAB6C gene is directly regulated by the protein p53 it is suggested to promote apoptosis [105]. RAB6C has also been shown to be able to inhibit the proliferation of breast cancer cells and decrease their invasion ability [70]. 


\section{Aims of the thesis}

\section{General aim}

The aim of this thesis is to identify prognostic and predictive factors in ER+ breast cancer. In particular we focused on factors that influence the long-term survival, as patients with ER+ tumors often live long and have higher risk of late recurrences than those with ER- tumors.

\section{Specific aims are}

To study the long-term prognosis related to AKT1 and AKT2 in ER+ breast cancer

To study the role of PR in relation to tamoxifen benefit in ER+ breast cancer

To identify new markers for subgroup division among patients with ER+/PRtumors and specifically validate prognostic and predictive importance of RAB6C 


\section{Comments on material and methods}

\section{Patients}

In all papers, data from a randomized trial conducted by the Stockholm Breast Cancer Study Group between 1976 and 1990 was used (Table 2). The patients were divided into a high-risk and a low-risk group, depending on the tumor size and lymph node status. For the low-risk patients, tamoxifen given post-operatively was compared with no adjuvant endocrine therapy. For the high-risk patients, chemotherapy was compared with RT. Data from the low-risk group was used for paper II, III, IV and data from the high-risk group for paper I and III. Vital status was collected from the Swedish Cause of Death Register. For paper III, we also used a public data set from National Center for Biotechnology Information (NCBI) with Dutch patients diagnosed between 1980 and 1995, who had node-negative, ER+ disease and did not receive adjuvant systemic therapy [106].

\section{Ethical considerations}

All procedures performed in the studies were in accordance with the ethical standards of the local ethical committee at the Karolinska University Hospital (KI 97451 with amendment 030201) and with the 1964 Helsinki declaration and its later amendments or comparable ethical standards. 
Table 2 Patients included in the papers

\begin{tabular}{|c|c|c|c|}
\hline $\begin{array}{l}\text { Years of } \\
\text { diagnosis }\end{array}$ & Inclusion criteria & Treatment & Paper \\
\hline \multirow[t]{3}{*}{1976 - 1990} & $\begin{array}{l}\text { Premenopausal patients, } \\
\mathrm{T}>30 \mathrm{~mm} \text { or } \mathrm{N} \geq 1\end{array}$ & & \\
\hline & & RT & III \\
\hline & & Chemotherapy & - \\
\hline \multirow[t]{5}{*}{$1976-1990$} & $\begin{array}{l}\text { Postmenopausal patients } \\
\leq 70 \text { years old, } \\
\mathrm{T}>30 \mathrm{~mm} \text { or } \mathrm{N} \geq 1\end{array}$ & & \\
\hline & & RT & 1 \\
\hline & & RT + Tamoxifen & 1 \\
\hline & & Chemotherapy & 1 \\
\hline & & $\begin{array}{l}\text { Chemotherapy + } \\
\text { Tamoxifen }\end{array}$ & I \\
\hline \multirow[t]{5}{*}{$1976-1990$} & $\begin{array}{l}\text { "Low-risk" } \\
\text { postmenopausal patients } \\
\leq 70 \text { years old, } \\
\mathrm{T} \leq 30 \mathrm{~mm} \text { and } \mathrm{NO}\end{array}$ & & \\
\hline & & Tamoxifen & II \& IV \\
\hline & & No tamoxifen & II \& III \& IV \\
\hline & & RT + Tamoxifen & II \& IV \\
\hline & & RT & II \& III \& IV \\
\hline \multirow[t]{2}{*}{$1980-1995$} & NO, ER+ & & \\
\hline & & $\begin{array}{l}\text { No adjuvant } \\
\text { systemic therapy }\end{array}$ & III \\
\hline
\end{tabular}




\section{The data material}

The data from the Stockholm randomized trial has several advantages. It was one of the first randomized studies to compare tamoxifen treatment versus control, before it was known that only patients with ER+ tumors had substantial benefit from tamoxifen. Therefore, the data contains a large number of patients that are systemically untreated and, since the patients were recruited independently of ER status, both those with ER+ and ER-tumors. This makes it possible to analyze the natural course in relation to different factors in patients with either ER+ or ERtumors. Furthermore, the follow-up time is long, over 20 years. On the other hand, the material has some limitations as it is old and the treatment has improved since then. The patients participating in the study received either two or five years of tamoxifen, whereas the endocrine treatment nowadays is given during at least five years.

\section{Protein expression determination}

Protein expression may be determined with different techniques, which have improved over time. ER assessment using cytosol assays have been compared with immunohistochemical staining (IHC) and was shown to provide similar results [107]. In our studies, we have used ER assessment as determined by IHC, while for tumors with missing data on ER by IHC, ER status according to the cytosol method was used.

For PR assessment, the concordance between ligand binding assays and $\mathrm{IHC}$ is more uncertain. Previous studies have shown that PR assays have more variation and are less accurate than those for ER [108]. 


\section{Cytosol assays}

Until approximately 1990, ER and PR were determined with biochemical methods by which the level of the receptors was measured in cytosol. Before 1988, the content of ER and PR was determined using isoelectric focusing (IF) on polyacrylamide gel [109111]. The tumor tissue was dissolved and mixed with radioactive estrogen which could bind to the receptors. Thereafter this mixture was put to migrate through a gel in order to separate the bounded protein from the rest. However, the receptors could be destroyed during the sensitive procedure and after 1988 it was replaced by an enzyme immunoassay (EIA). This method was more reliable since specific antibodies for the receptors were used [112-114]. The cytosol method was timeconsuming, required large amounts of tumor material and ER and PR receptor content was measured in tumor tissue consisting of both cancer cells and stromal cells. However, an advantage of the method was the possibility of absolute quantification.

\section{Immunohistochemical staining (IHC)}

Generally, when IHC is used, the tumor tissue is fixed and unspecific binding sites are blocked before adding a primary antibody that binds to the target antigen in the tissue. Thereafter, a labeled secondary antibody that reacts with the primary antibody is used. Counterstaining and glass slide mounting is performed before evaluation.

IHC is a cheap, less time-consuming method for which formalin fixated paraffin embedded tissues may be used. Nowadays IHC is routinely used by pathologists for clinical evaluation of protein expression in tissues, e.g., ER and PR assessment. In this thesis we determined RAB6C expression using IHC. The possibility to determine subcellular location is an advantage of the method, but problems with reproducibility and lack of specific antibodies are challenging problems as well as subjective 
determination. In order to reduce this problem, the IHC determinations in this thesis were performed blinded and of at least two independent observers.

\section{Statistics}

\section{Subgroup analyses}

The papers in the thesis include subgroup analyses. Such analyses should always be performed and interpreted with caution. If subgroups are created ad hoc, there is an extensive risk that at least one subgroup shows significant result even though this is not true (type I error). To avoid this problem, we have defined the subgroups in advance, based on well-known clinical subgroups. Another possibility to adjust for multiple analyses is to apply Bonferroni adjustment, though it may be claimed to be too conservative. One should also be aware of the fact that subgroup-specific analyses are affected by many factors and should rather be based on formal tests of interactions. An interaction describes a situation where the effect of two independent variables on a third is not additive, i.e. the effect of one independent variable may depend on the level of the other independent variable. Though, most studies are underpowered for detecting interaction effects [115-118].

\section{Survival analysis}

Survival curves were estimated using the Kaplan-Meier approach, which provides a nonparametric estimate of the survival probability of an event of interest [119].

In order to relate risk factors (covariates) to survival time, we applied Cox proportional hazard regression analysis [120]. The model is called semi-parametric, since it is non-parametric with respect to time but parametric in terms of the covariates. The hazard rate refers to the instantaneous rate of failure (for example 
recurrence or death) during the next instant of time, given that the patient has survived until a specific time. When we compare two independent groups, we estimate the hazard ratio $(\mathrm{HR})$. This is the ratio of the hazard rates between the two independent comparison groups [121]. The HR estimates how many times higher or lower the risk of event is for one group compared with the reference group. If HR exceeds 1, it means a higher risk of event and HR less than 1 means a lower risk of event. HR is reported with a $95 \%$ confidence interval $(\mathrm{Cl})$, which means that if we were to draw several independent, random samples from the same population and calculate $95 \% \mathrm{Cl}$ from each of them, then on average $95 \%$ such $\mathrm{Cl}$ would contain the true population HR [122]. The p-values are obtained from two-sided Wald tests. For appropriate use of Cox proportional hazard regression model, some assumptions must be fulfilled:

a) the hazard ratio is constant over time (proportional hazards)

b) independent censoring (i.e. the items may not be censored because they have a higher or lower risk than the average, given the covariates)

c) a multiplicative relationship between the covariates and the hazard

\section{Subpopulation treatment effect pattern plot (STEPP)}

STEPP is an exploratory technique for graphical testing of interactions between treatment and continuous covariates [123]. It considers sequences of potentially overlapping subpopulations defined with respect to a covariate and is especially useful when trying to identify subpopulations of patients for whom the overall trial results may be less representative. There are several advantages of the method, e.g., that no assumptions about the nature of the relationship between the outcome and the covariate in each treatment group must be done and that it avoids dichotomization of covariates, which may be subjective. Though, the size of the subpopulations is critical to the performance of the method and, hence, to the interpretation of the results $[124,125]$. In paper II, we used STEPP to investigate the interaction between continuous PR values and the effect of tamoxifen. To avoid 
results based on one single subgroup division, we performed the STEPP analysis with different numbers of subgroups and ensured that the achieved results were similar independently of the chosen number of subgroups.

\section{SNP selection among whole genome gene copy data}

In paper III, we used a public data set including whole genome gene copy data of 199 patients. We defined the most varying single-nucleotide polymorphism (SNPs) as those with the largest interquartile range (IQR), i.e. the SNPs where the middle $50 \%$ has the largest variation among the patients. For the 20 most varying SNPs, the patients were divided into two groups with the median value of gene copies as cutoff. In order to investigate the prognostic value of each of the 20 SNP separately, the cumulative distant-recurrence risk was plotted and HRs with $95 \% \mathrm{Cl}$ were estimated.

The selecting approach using IQR implies that we select SNPs that vary a lot for relatively large groups of patients, whereas we do not identify rare SNPs with large variation. For example, the HER2 gene, which is known to be amplified among about $15 \%$ of the patients, did not come up among the top varying SNPs. On the other hand, by excluding the upper and lower $25 \%$ of the values, we do not risk to deal with outliers. The approach to compute the IQR for SNPs has been applied previously [126].

The selected number of SNPs and the fact that we choose the middle $50 \%$ may be questioned. For example, choosing the middle $90 \%$ instead would result in other top varying SNPs. Furthermore, SNPs that are nearby are highly correlated, implying that there is a high risk that several SNPs that are located close to each other are chosen. One strength of our method is that it is a simple approach to filter out SNPs with consistently low values or low variance across the samples. Performing this method, we identified the gene $R A B 6 C$ as a prognostic marker. The statistical finding of $R A B 6 C$ as an interesting prognostic factor was supported by the literature, which brought us to perform further experiments on the protein $\operatorname{RAB} 6 C[69,70,104,105,127-130]$. 


\section{Results and discussion}

\section{Paper I}

Besides conventional prognostic factors, such as nodal status and tumor size, several biomarkers are claimed to provide prognostic information, but many of them need further follow-up to confirm long-term effects [131]. In paper I, we revealed the different roles of AKT1 and AKT2 and their long-term significance in relation to prognosis. We showed that for patients with ER+tumors, AKT2 is an independent prognostic factor for distant recurrence-free survival. In contrast to many well-known prognostic factors, the significance of AKT2 remained several years after diagnosis. In a multivariable analysis for ER+ tumors including established clinical factors, the risk reduction was $62 \%$ for patients with tumors expressing AKT2 (AKT2+) compared with those which did not express AKT2 (AKT2-) (HR =0.38, 95\% Cl 0.21-0.68, $p=0.001)$. For patients with ER-tumors there was no statistical significant difference in distant recurrence-free survival $(\mathrm{HR}=1.24,95 \% \mathrm{Cl} 0.56-2.73, \mathrm{p}=0.59)$. For patients with tumors expressing AKT1 (AKT1+) we could not show prolonged or shortened distant recurrence-free survival compared with patients whose tumors did not express AKT1 (AKT1-), irrespective of ER status: ER- tumors, $\mathrm{HR}=0.98$ ( $95 \% \mathrm{Cl} 0.50-1.91, \mathrm{p}=0.95)$; $E R+$ tumors, $H R=0.89(95 \% \mathrm{Cl} 0.58-1.38, p=0.61)$.

In order to investigate whether AKT1 or AKT2 has a long-term significance on prognosis for patients with ER+ tumors, we performed a multivariable analysis dividing the follow-up period into two different time intervals, before and after 5 years since diagnosis. While tumor size failed to provide long-term prognostic information, AKT2 remained statistically significant even after 5 years ( $H R=0.43,95 \%$ $\mathrm{Cl} 0.19-0.97, \mathrm{p}=0.043)$. For AKT1, there was no statistical significance and the HR was approximately 1 independently of time period (Table 3). 
Table 3 Multivariable analysis of distant recurrence-free survival for patients with ER+ tumors by follow-up period ${ }^{\mathrm{a}}$

\begin{tabular}{|c|c|c|c|c|}
\hline & \multirow{2}{*}{$\begin{array}{c}<5 \text { years } \\
\text { HR }\end{array}$} & \multicolumn{3}{|c|}{$\geq 5$ years } \\
\hline & & $95 \% \mathrm{Cl}$ & $\mathrm{HR}$ & $95 \% \mathrm{Cl}$ \\
\hline AKT1 (pos. vs. neg.) & 1.08 & $0.55-2.10$ & 1.03 & $0.50-2.13$ \\
\hline AKT2 (pos. vs. neg.) & $0.32 *$ & $0.13-0.78$ & $0.43^{*}$ & $0.19-0.97$ \\
\hline pAKT ${ }^{\mathrm{b}}$ (pos. vs. neg.) & 0.94 & $0.52-1.70$ & 1.00 & $0.51-1.98$ \\
\hline Tumor size (>20 vs. $\leq 20$ ) & $2.09 *$ & $1.12-3.87$ & 1.22 & $0.59-2.52$ \\
\hline Nodal status (1-3 vs. 0) & 3.11 & $0.70-13.7$ & 1.33 & $0.40-4.46$ \\
\hline (4-vs. 0) & $4.64 *$ & $1.02-21.0$ & $3.94 *$ & $1.08-14.4$ \\
\hline HER2 (pos. vs. neg.) & 1.14 & $0.59-2.19$ & 1.22 & $0.52-2.87$ \\
\hline PIK3CA ${ }^{c}$ (mutated vs. wt ${ }^{d}$ ) & 1.06 & $0.55-2.02$ & 1.09 & $0.53-2.25$ \\
\hline Tamoxifen (yes vs. no) & $0.41 * *$ & $0.22-0.76$ & 0.54 & $0.28-1.07$ \\
\hline $\mathrm{CMF}^{\mathrm{e}}$ (yes vs. no) & 0.87 & $0.49-1.55$ & 0.89 & $0.46-1.72$ \\
\hline
\end{tabular}

$* p<0.05, * * p<0.01$

a) Multivariable analysis was performed for patients where we had data on all variables included (163 patients for the first time period and 110 patients for the second time period)

b) $\mathrm{pAKT}=$ activated $\mathrm{AKT}$

c) PIK3CA = phosphatidylinositol 3-kinase catalytic subunit alpha

d) $\mathrm{wt}=$ wildtype

e) $\mathrm{CMF}=$ cyclophosphamide, methotrexate and fluorouracil

The ER+ tumors were further divided into two groups with intermediate levels of ER (between 0.1 and $1.0 \mathrm{fmol} / \mu \mathrm{g}$ DNA) and high levels ( $\geq 1.0 \mathrm{fmol} / \mu \mathrm{g}$ DNA). A test for trend showed that the prognostic significance of AKT2 increased with higher estrogen receptor expression from $\mathrm{HR}=1.00(95 \% \mathrm{Cl} 0.53-1.87, \mathrm{p}=1.00)$ for patients with $E R$ tumors to $\mathrm{HR}=0.67(95 \% \mathrm{Cl} 0.35-1.27, \mathrm{p}=0.22)$ for intermediate levels of $E R$ to $H R=$ $0.32(95 \% \mathrm{Cl} 0.14-0.77, \mathrm{p}=0.010)$ for high levels of ER ( $\mathrm{P}$ for trend=0.042) (Fig. 6 and Fig. 7). 

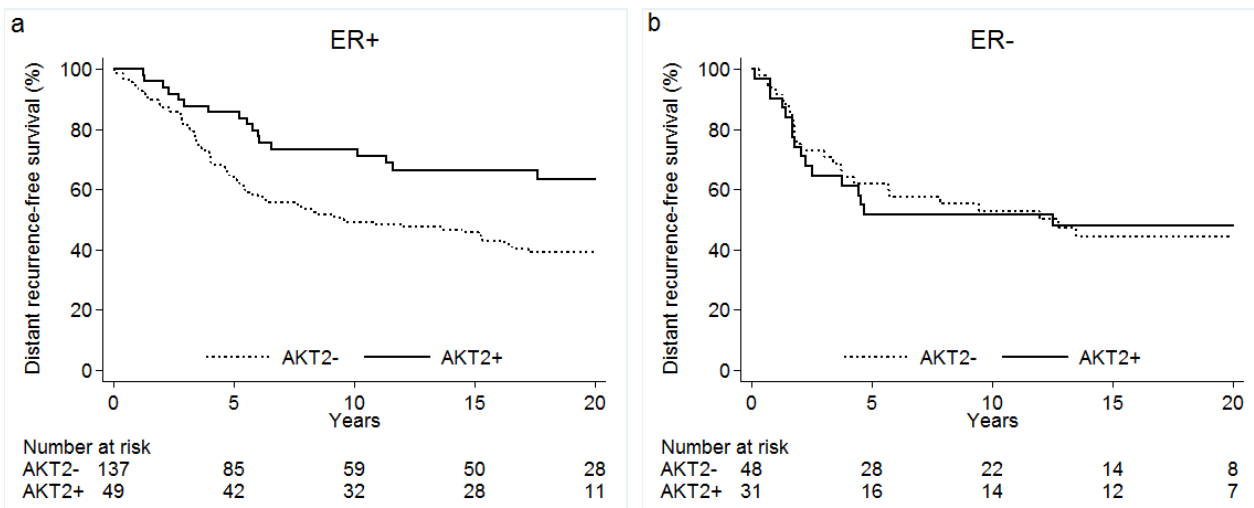

Fig. 6 Distant recurrence-free survival in relation to AKT2 for patients with $E R+$ tumors, $H R=0.49$ $(95 \% \mathrm{Cl} 0.29-0.82, \mathrm{p}=0.007)$ (a) and ER- tumors, $\mathrm{HR}=1.00$ (95\% $\mathrm{Cl} 0.53-1.87, \mathrm{p}=1.00)$ (b)

a

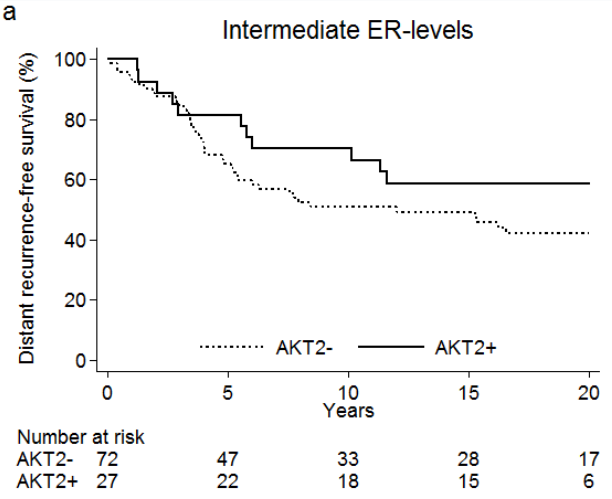

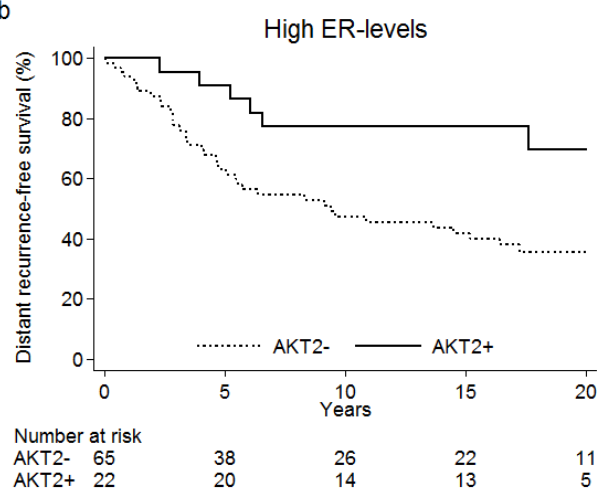

Fig. 7 Distant recurrence-free survival in relation to AKT2 for patients with tumors with intermediate ER-levels $(0.1 \leq \mathrm{ER}<1.0 \mathrm{fmol} / \mu \mathrm{g} D N A), \mathrm{HR}=0.67$ (95\% $\mathrm{Cl} 0.35-1.27, \mathrm{p}=0.22)$ (a) and high ER-levels $(\geq 1.0 \mathrm{fmol} / \mu \mathrm{g} \mathrm{DNA}), \mathrm{HR}=0.32(95 \% \mathrm{Cl} 0.14-0.77, \mathrm{p}=0.010)(\mathrm{b})$ 
The better prognosis for patients with ER+ tumors and AKT2 expression was more pronounced in the combination of AKT2+ and activated AKT (pAKT+) (HR=0.31, 95\% $\mathrm{Cl} 0.13-0.73, \mathrm{p}=0.007)$ compared with non-activated AKT (pAKT-) (HR=0.71, 95\% Cl $0.37-1.37, p=0.30$ ) (Fig. 8) A test for interaction between ER status and the combined AKT2/pAKT status showed statistical significance $(p=0.015)$ with respect to prognosis.


Fig. 8 Distant recurrence-free survival in relation to AKT2 for patients with $E R+/ p A K T+$ tumors, $H R=$ $0.31(95 \% \mathrm{Cl} 0.13-0.73, \mathrm{p}=0.007)$ (a) and $\mathrm{ER}+/ \mathrm{pAKT}$ - tumors, $\mathrm{HR}=0.71(95 \% \mathrm{Cl} 0.37-1.37, \mathrm{p}=0.30)$ (b)

The specific functions of AKT1 and AKT2 are mainly due to partly different subcellular locations and interactions with different proteins [99]. Studies about the prognostic value of AKT show partly different results [98]. One reason may be that the antibodies could not distinguish between the isoforms, and since they act in different ways, they may show contradictive results. Probably, isoform specific inhibitors are needed, though the high homology may cause a problem in developing such inhibitors. 


\section{Paper II}

The clinical value of PR status has been discussed in various studies $[80,81,83,132$, 133]. One argument against PR determination has been that PR has very little therapeutic impact since more than $99 \%$ of the ER- patients are also PR-, and ER+ patients receive endocrine therapy independently of PR status [132]. On the other hand, the St Gallen Criteria emphasize the significance of PR status for the oncologic therapy, where ER+/PR- are recommended a more aggressive treatment than $\mathrm{ER}+/ \mathrm{PR}+[40]$. In paper II, we aimed to rule out the predictive value of PR (determined by $\mathrm{IHC}$ ) in relation to tamoxifen benefit, in particular the long-term effect. We evaluated 618 patients with ER+ "low-risk" breast cancer (size $\leq 30 \mathrm{~mm}$, lymph nodenegative) for whom PR was determined by IHC at one pathology laboratory. PR was defined as PR+ if there was $\geq 10 \%$ stained cells.

Our results showed that tamoxifen had slightly more effect on the recurrence risk for patients with $E R+/ P R+$ than $E R+/ P R$ - tumors the first five years $E R+/ P R+: H R=0.27$ (95 \% Cl: $0.14-0.53), p<0.001, E R+/ P R-: H R=0.39(95 \% \mathrm{Cl}: 0.15-1.00), p=0.05$.

Thereafter, the relative risk ratio increased more for patients with ER+/PR- tumors (HR after 5 years $=1.34(95 \% \mathrm{Cl}: 0.69-2.60, \mathrm{p}=0.39)$ compared with $E R+/ P R+(H R$ after 5 years $=0.55(95 \% \mathrm{Cl}: 0.34-0.88, \mathrm{p}=0.012)$. (Fig. 9)
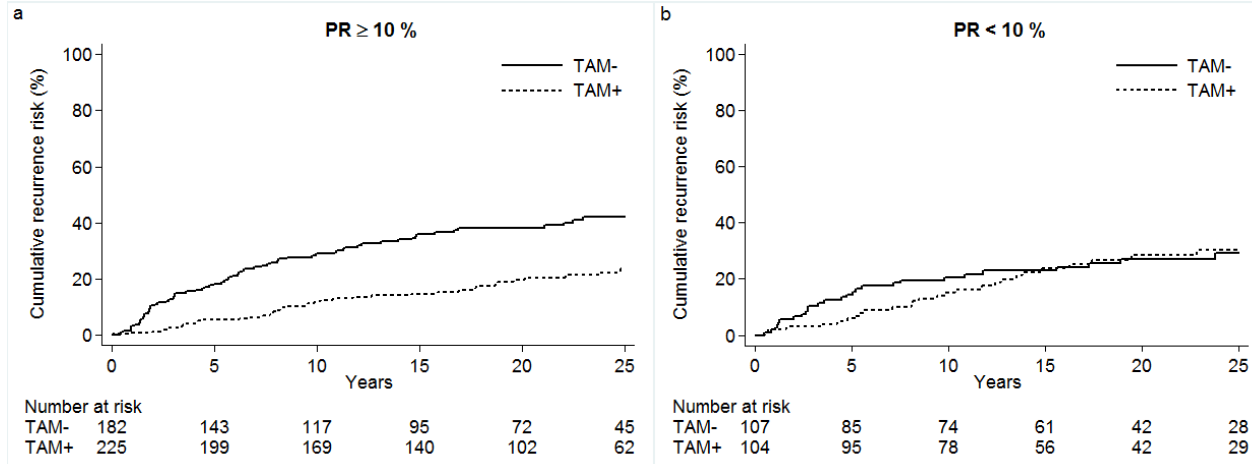

Fig. 9 Cumulative recurrence risk for patients with $E R+/ P R+$ tumors, $H R=0.43(95 \% \mathrm{Cl} 0.29-0.62, p<$ $0.001)$ (a) and $E R+/ P R-$ tumors, $H R=0.87(95 \% \mathrm{Cl} 0.52-1.46, p=0.59)$ (b) 
We further investigated how the tamoxifen effect varied over different levels of PR, both using subgroups based on cut-offs at $1 \%, 10 \%, 50 \%$ and $75 \%$ stained cells, as well as performing STEPP analysis where previously determined cut-off values are not needed. The results from both analyses showed that at all receptor levels with $\geq 10 \%$ stained cells there was a benefit from tamoxifen (Fig. 10 and Table 4). The STEPP analysis also indicated some effect of tamoxifen even in patients with ER+/PR- tumors the first five years after diagnosis, which is in line with the results in Table 4 (Fig. 11).
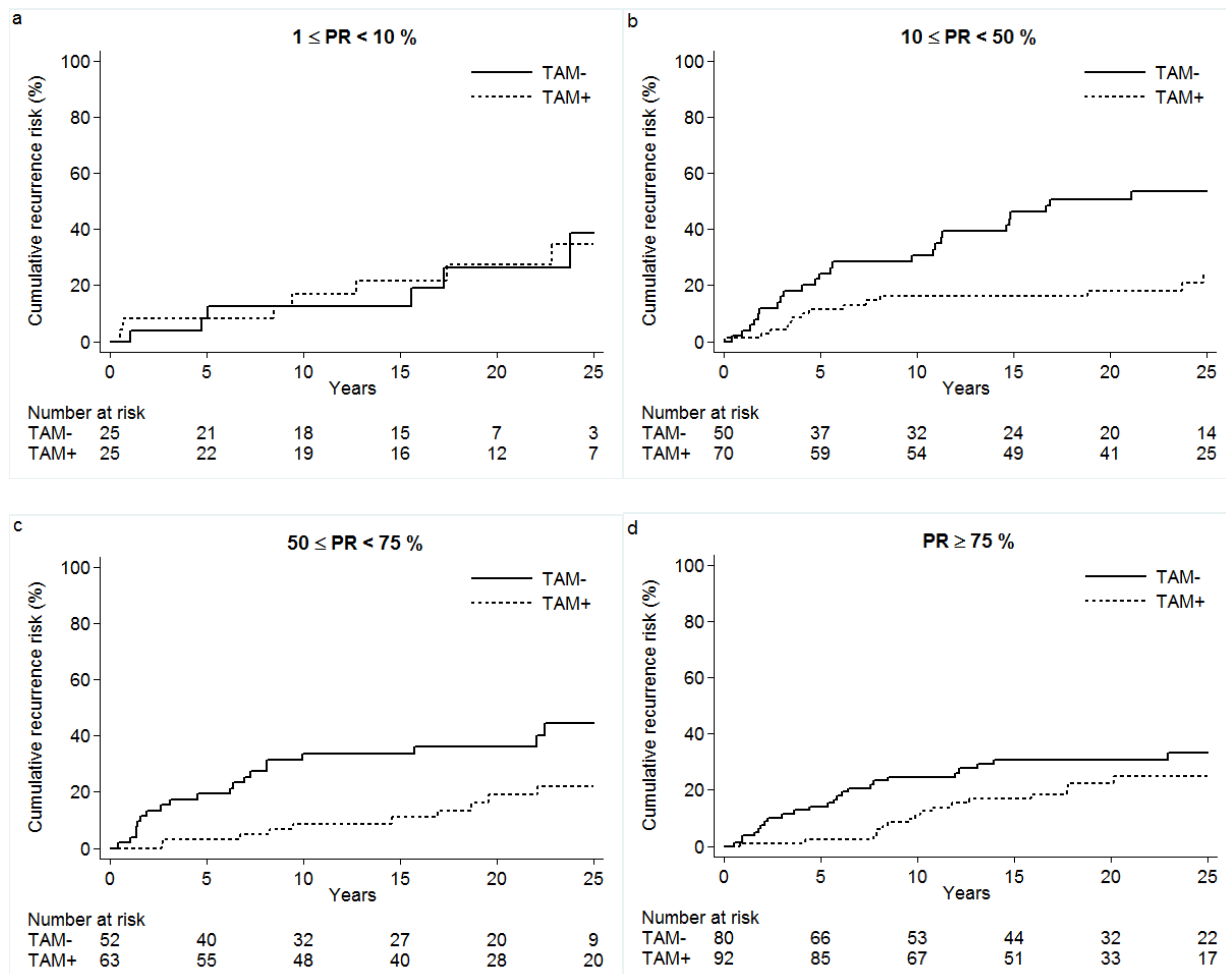

Fig. 10 Influence of increasing proportion of PR-positive tumor cells on cumulative recurrence risk among patients with ER-positive tumors. PR 1 - $9 \%, H R=1.11$ ( $95 \% \mathrm{Cl} 0.38-3.24), p=0.84$ (a), PR 10 $-49 \%, \mathrm{HR}=0.30$ (95\% Cl $0.16-0.58), \mathrm{p}<0.001$ (b), PR $50-74 \%, \mathrm{HR}=0.38(95 \% \mathrm{Cl} 0.18-0.80), \mathrm{p}=$ 0.011 (c), $P R \geq 75 \%, H R=0.59$ (95\% Cl $0.32-1.08), p=0.086$ (d) 
Table 4 Outcome for patients with ER positive tumors divided by different levels of PR (IHC) expression and different time periods

\begin{tabular}{|c|c|c|c|c|c|c|c|c|c|}
\hline \multirow{3}{*}{ Tam vs. control } & \multirow{3}{*}{ PR (IHC) } & \multicolumn{3}{|c|}{$0-5$ years } & \multicolumn{5}{|c|}{ Beyond 5 years } \\
\hline & & \multicolumn{2}{|c|}{$\begin{array}{c}\text { Number of } \\
\text { Patients/Events }\end{array}$} & \multirow[t]{2}{*}{$\begin{array}{c}\mathrm{HR} \\
(95 \% \mathrm{Cl})\end{array}$} & \multirow[t]{2}{*}{$\begin{array}{l}P \\
\text { value }\end{array}$} & \multicolumn{2}{|c|}{$\begin{array}{c}\text { Number of } \\
\text { Patients/Events }\end{array}$} & \multirow[t]{2}{*}{$\begin{array}{c}\text { HR } \\
(95 \% \mathrm{Cl})\end{array}$} & \multirow[t]{2}{*}{$\begin{array}{l}P \\
\text { value }\end{array}$} \\
\hline & & TAM & Control & & & TAM & Control & & \\
\hline Recurrence & $0 \%$ & $79 / 4$ & $82 / 13$ & $0.29(0.09-0.89)$ & 0.031 & $73 / 15$ & $64 / 11$ & $1.34(0.62-2.93)$ & 0.46 \\
\hline \multirow[t]{4}{*}{ rate } & $1-9 \%$ & $25 / 2$ & $25 / 2$ & $1.07(0.15-7.56)$ & 0.95 & $22 / 6$ & $21 / 4$ & $1.14(0.32-4.05)$ & 0.85 \\
\hline & $10-49 \%$ & $70 / 8$ & $50 / 12$ & $0.44(0.18-1.07)$ & 0.069 & $59 / 6$ & $37 / 15$ & $0.21(0.08-0.54)$ & 0.001 \\
\hline & $50-74 \%$ & $63 / 2$ & $52 / 10$ & $0.15(0.03-0.69)$ & 0.015 & $55 / 9$ & $40 / 10$ & $0.59(0.24-1.46)$ & 0.26 \\
\hline & $\geq 75 \%$ & $92 / 2$ & $80 / 11$ & $0.15(0.03-0.67)$ & 0.013 & $85 / 16$ & $66 / 14$ & $0.93(0.45-1.91)$ & 0.85 \\
\hline
\end{tabular}
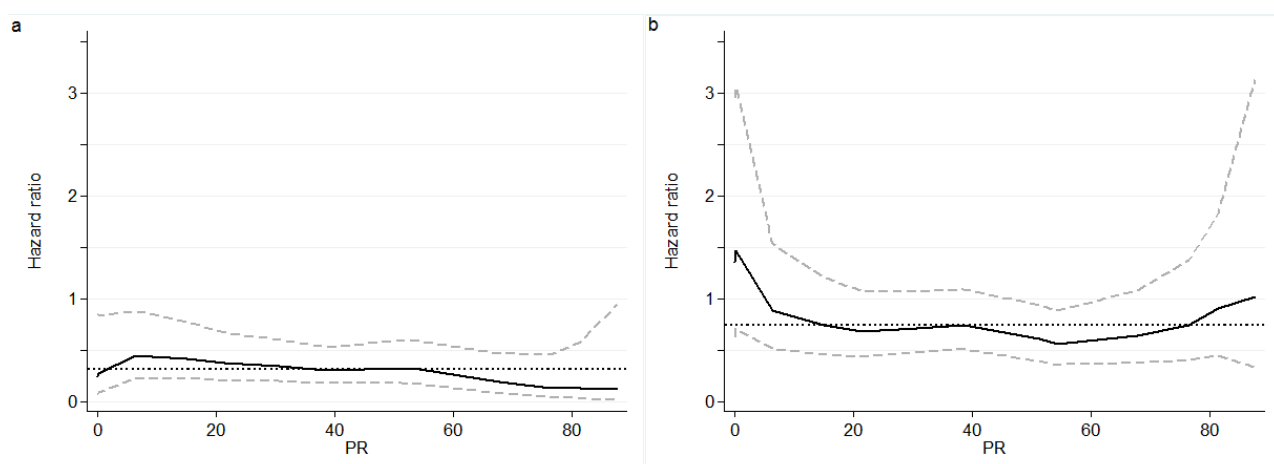

Fig. 11 Subpopulation treatment effect pattern plots (STEPP), showing the effect of tamoxifen vs. control on the recurrence risk during the first five years after diagnosis (a), more than five years after diagnosis (b) in relation to PR values measured with IHC. HR (solid black line) with the corresponding $95 \%$ confidence interval (dashed grey lines) is plotted against the mean PR for overlapping subgroups. The dotted black line shows the HR for tamoxifen vs. control for all PR values in the selected time period. 
Our results are partially contradictory to the data in the Early Breast Cancer Trialists' Collaborative Group (EBCTCG) review where PR did not add predictive value for tamoxifen to ER alone [134]. As explained below, we suggest three possible reasons for the contradictive results: a) the method of PR determination, b) a time-dependent effect and c) use of chemotherapy.

a) Most PR values in the EBCTCG overview were obtained with cytosol based assays. In our cohort, cytosol PR information was also available and in agreement with the EBCTCG review, PR positivity determined with cytosol assay did not predict tamoxifen benefit more efficiently than ER positivity alone $E R+/ P R+: H R=0.45(0.28-0.72, p=$ $0.001)$, ER+/PR-: $H R=0.48(0.27-0.87, p=0.015)$. In the EBCTCG overview it is stated that $21 \%$ of the ER-negative cancers were PR positive, indicating that the PR technique used resulted in many false positive PR classifications.

b) As the follow-up period in the present study was long and the predictive value for PR was most evident beyond 5 years of follow-up, it may indicate a time-dependence of the ability of PR to predict the efficacy of adjuvant tamoxifen.

c) The patients in the present study did not receive adjuvant chemotherapy. Potential differences in tamoxifen benefit in relation to PR levels could possibly be masked by the effect of chemotherapy, in particular in cohorts where the use of chemotherapy is not balanced between patients with $E R+/ P R+$ and $E R+/ P R-$ tumors. 


\section{Paper III}

The aim of paper III was to identify new prognostic factors among patients with ER+ tumors. We specifically aimed to investigate if these factors have prognostic value in subgroups based on PR. Using the public data set with accession number GSE10099 including whole genome gene copy data, available at the National Center for Biotechnology Information (NCBI) website, we identified one candidate gene, RAB6C, for subgroup division among patients with ER+/PR- tumors. Our results suggested that if there were few gene copies of $R A B 6 C$, it was related to poor prognosis. For patients with $\mathrm{ER}+/ \mathrm{PR}$ - tumors, there was a risk reduction of $77 \%(\mathrm{HR}=0.23,95 \% \mathrm{Cl}$ : $0.08-0.61, p=0.003)$ if the tumor had gene copies above the median value $(R A B 6 C+)$ compared with below (RAB6C-). Even for patients with ER+/PR+ tumors, $R A B 6 C$ had a favorable prognostic value, though it was associated with less risk reduction (HR= 0.55, 95\% Cl: $0.32-0.96, p=0.03$ ) (Fig. 12 and Table 5).
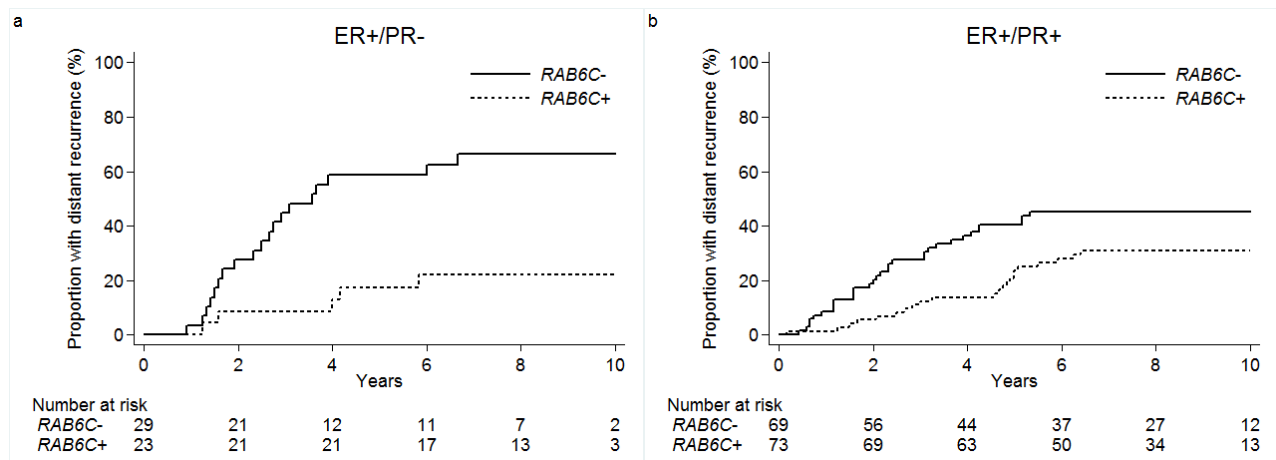

Fig. 12 Cumulative distant recurrence risk in relation to gene copy number of $R A B 6 C$ for patients with $E R+/ P R-, H R=0.23$ (95\% Cl: $0.08-0.61), p=0.003$ (a) and $E R+/ P R+, H R=0.55$ (95\% Cl: $0.32-0.96)$, $\mathrm{p}=0.03(\mathrm{~b})$ tumors in the public data set 
Table 5 Distant recurrence rate in the public data set for $R A B 6 C+$ compared with $R A B 6 C$ - divided by hormone receptor status. $R A B 6 C$ - is the referent (with $\mathrm{HR}=1$ ) in each subgroup analysis.

\begin{tabular}{|c|c|c|c|c|c|c|}
\hline \multirow{3}{*}{$\begin{array}{l}\text { Hormone receptor } \\
\text { status }\end{array}$} & & & \multicolumn{2}{|l|}{ Univariable } & \multicolumn{2}{|l|}{ Multivariable* } \\
\hline & \multicolumn{2}{|c|}{$\begin{array}{c}\text { Number of } \\
\text { Patients/Events }\end{array}$} & \multirow[t]{2}{*}{$\mathrm{HR}(95 \% \mathrm{Cl})$} & \multirow[t]{2}{*}{$P$ value } & \multirow[t]{2}{*}{$\mathrm{HR}(95 \% \mathrm{Cl})$} & \multirow[t]{2}{*}{$P$ value } \\
\hline & $R A B 6 C+$ & $R A B 6 C-$ & & & & \\
\hline $\mathrm{ER}+$ & $99 / 28$ & $100 / 50$ & $0.44(0.28-0.71)$ & 0.001 & $0.45(0.28-0.72)$ & 0.001 \\
\hline $\mathrm{ER}+/ \mathrm{PR}+$ & $73 / 22$ & $69 / 31$ & $0.55(0.32-0.96)$ & 0.034 & $0.55(0.32-0.95)$ & 0.033 \\
\hline$E R+/ P R-$ & $23 / 5$ & 29/19 & $0.23(0.08-0.61)$ & 0.003 & $0.15(0.05-0.46)$ & 0.001 \\
\hline
\end{tabular}

*Multivariable analysis for ER+ tumors adjusted for age, tumor stage, grade and PR. The multivariable analysis confined to the subgroups ER+/PR+ and ER+/PR- adjusted for age, tumor stage and grade

We also determined the protein expression of RAB6C in an independent cohort with similar results. High expression of RAB6C (RAB6C+) compared with low expression (RAB6C-) among patients with ER+/PR- tumors implied better prognosis ( $H R=0.24$, 95\% Cl: $0.09-0.66, p=0.005)$ whereas we could not show statistical significance for patients with $E R+/ P R+$ tumors ( $H R=1.20,95 \% \mathrm{Cl}: 0.66-2.19, p=0.55)$ (Fig. 13). Adjusting for age, tumor size, lymph node status, HER2, grade, and PR in a multivariable analysis including patients with $\mathrm{ER}+$ tumors, RAB6C retained its prognostic importance, which was stronger for patients with ER+/PR-tumors as indicated by a statistically significant interaction between PR and RAB6C $(p=0.005)$. Stratifying the results of the multivariable analysis according to PR status, the distant recurrence rate for RAB6C+ versus RAB6C- was clearly reduced among patients with $E R+/ P R$ - tumors ( $\mathrm{HR}=0.17,95 \% \mathrm{Cl}: 0.05-0.60, \mathrm{p}=0.006)$, but not in patients with $E R+/ P R+$ tumors $(H R=1.31,95 \% \mathrm{Cl} 0.69-2.48, p=0.41)$ (Table 6). 
a

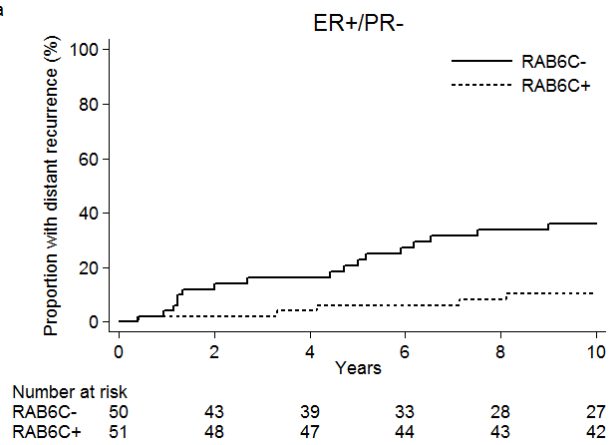

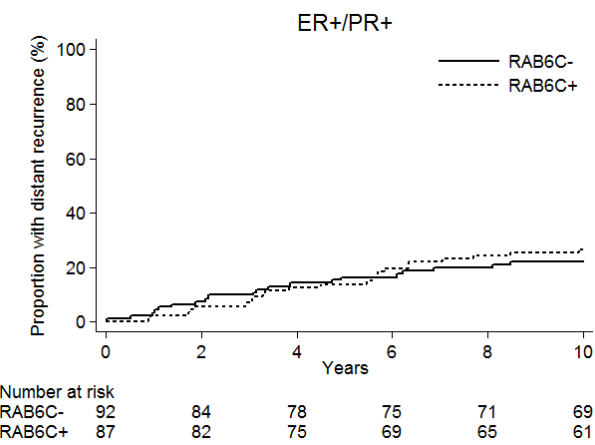

Fig. 13 Cumulative distant recurrence risk in relation to protein expression of RAB6C for patients with $E R+/ P R-, H R=0.24(95 \% \mathrm{Cl}: 0.09-0.66), p=0.005$ (a) and $E R+/ P R+, H R=1.20(95 \% \mathrm{Cl}: 0.66-2.19), p=$ 0.55 (b) tumors in the independent cohort

Table 6 Distant recurrence rate in the independent cohort for RAB6C+ compared with RAB6Cdivided by hormone receptor status. RAB6C- is the referent (with $H R=1$ ) in each subgroup analysis.

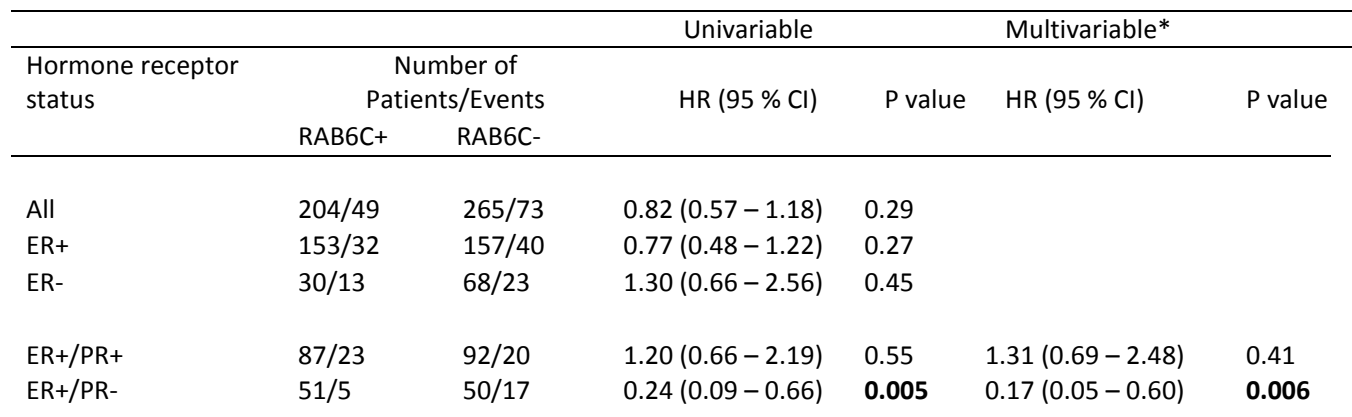

*Multivariable analysis confined to ER+ tumors, including age, tumor size, lymph node status, HER2, grade, PR and the interaction term PR $\times$ RAB6C

In summary, at the first step, we analyzed whole genome gene copy data. By a statistic approach and support from the literature, which suggests interesting properties of RAB6C, this gene was selected and the protein expression was further analyzed in an independent cohort $[69,70,104,105,127-130]$. The prognostic value of RAB6C was significant both at gene copy level and protein expression level. RAB6C has been shown to serve as a useful biomarker and to have prognostic significance even among other cancer forms $[135,136]$. An interesting aim for future experimental studies is to rule out the function of the protein. 


\section{Paper IV}

In paper II, we showed that patients with ER+/PR+ tumors clearly did benefit from tamoxifen, while the long-term benefit was less for those with ER+/PR-tumors. However, patients with ER+/PR- tumors are a heterogeneous group and among them there might be subgroups of patients that do benefit from tamoxifen. The results from paper III indicated that RAB6C is a prognostic marker for subgroup division of ER+/PR- tumors. Therefore, the aim of paper IV was to investigate if RAB6C has a treatment predictive value for tamoxifen. Patients with ER+ tumors did benefit from tamoxifen and it was most evident among those with $E R+/ P R+$ tumors $(H R=0.39,95$ $\% \mathrm{Cl}: 0.23-0.67, \mathrm{p}=0.001)$ compared with those with $\mathrm{ER}+/ \mathrm{PR}$ - tumors (HR=0.65, 95 $\% \mathrm{Cl}: 0.34-1.25, \mathrm{p}=0.19)$. For the $\mathrm{ER}+/ \mathrm{PR}+$ subgroup, patients with either $\mathrm{RAB} 6 \mathrm{C}+$ or RAB6C- tumors did benefit from tamoxifen, although it was statistical significant only among RAB6C+: HR (RAB6C+)=0.27 (95\% Cl: $0.13-0.58, \mathrm{p}=0.001)$ and HR (RAB6C-)= $0.63,95 \% \mathrm{Cl}: 0.29-1.37, \mathrm{p}=0.24)$, respectively. Among patients with $E R+/ P R-$ tumors, we could only show a statistical significant tamoxifen benefit for RAB6C- with $\mathrm{HR}=0.25(95 \% \mathrm{Cl}: 0.09-0.70, \mathrm{p}=0.008)$ whereas the point estimate for RAB6C+ even was in the opposite direction with $\mathrm{HR}=1.82(95 \% \mathrm{Cl}: 0.69-4.79, \mathrm{p}=0.23)$ (Table 7 and Fig. 14). The statistical significant interaction $(p=0.004)$ also indicated a different effect of tamoxifen among ER+/PR-tumors depending on RAB6C status. 
Table 7 Univariable analysis of distant recurrence rates for tamoxifen (TAM) treated patients compared with the control group divided by hormone receptor status. The control group is the referent (with $\mathrm{HR}=1$ ) in each subgroup analysis.

\begin{tabular}{llcrll}
\hline \multicolumn{5}{c}{ Subgroup } & \multicolumn{3}{c}{$\begin{array}{c}\text { Number of } \\
\text { Patients/Events }\end{array}$} & HR $(95 \% \mathrm{Cl})$ & P value & P for interaction \\
& TAM+ & TAM- & & \\
\hline ER+ & $259 / 35$ & $227 / 61$ & $0.47(0.31-0.71)$ & $<0.001$ & \\
ER+/PR+ & $177 / 20$ & $143 / 39$ & $0.39(0.23-0.67)$ & $\mathbf{0 . 0 0 1}$ & 0.20 \\
ER+/PR- & $82 / 15$ & $84 / 22$ & $0.65(0.34-1.25)$ & 0.19 & \\
ER+/PR+/RAB6C+ & $111 / 10$ & $75 / 22$ & $0.27(0.13-0.58)$ & $\mathbf{0 . 0 0 1}$ & 0.14 \\
ER+/PR+/RAB6C- & $66 / 10$ & $68 / 17$ & $0.63(0.29-1.37)$ & 0.24 & \\
& & & & & \\
ER+/PR-/RAB6C+ & $37 / 10$ & $41 / 7$ & $1.82(0.69-4.79)$ & 0.004 \\
ER+/PR-/RAB6C- & $45 / 5$ & $43 / 15$ & $0.25(0.09-0.70)$ & $\mathbf{0 . 0 0 8}$ & \\
& & & & & \\
\hline
\end{tabular}



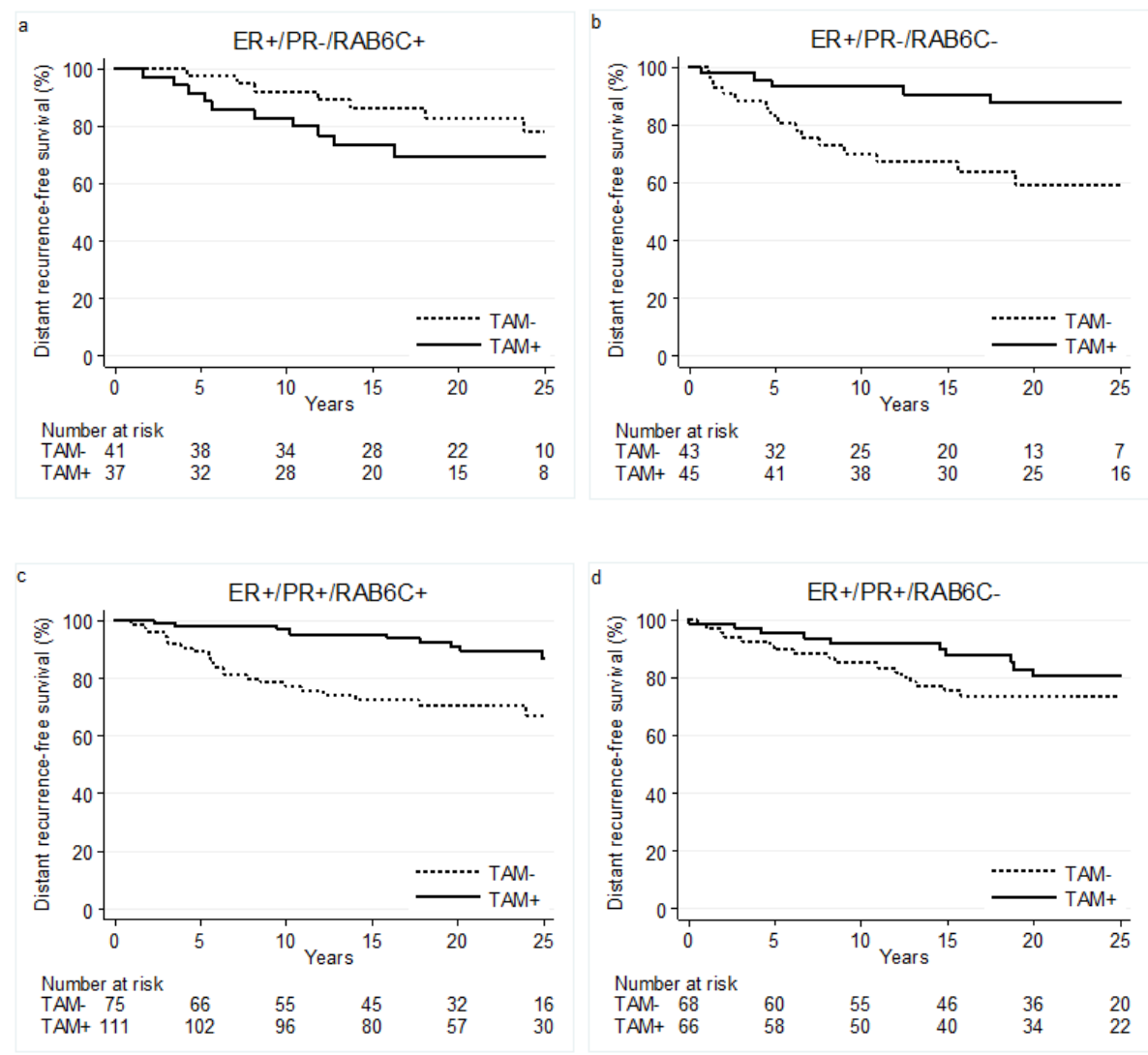

Fig. 14 Distant recurrence-free survival in relation to tamoxifen (TAM) for patients with ER+/PR/RAB6C+, HR= 1.82 (95 \% Cl $0.69-4.79$ ), $p=0.23$ (a) ER+/PR-/RAB6C-, HR= 0.25 (95\% Cl $0.09-0.70$ ), $\mathrm{p}=0.008$ (b) $E R+/ P R+/ R A B 6 C+, H R=0.27(95 \% \mathrm{Cl} 0.13-0.58), p=0.001$ (c) ER+/PR+/RAB6C-, HR= $0.63(95 \% \mathrm{Cl} 0.29-1.37), p=0.24$ (d)

Among patients with ER+/PR-tumors, more specific subgroups are needed and our results may contribute to identification of such subgroups. The results suggest that patients with ER+/PR- tumors and low RAB6C expression do benefit from tamoxifen, whereas this could not be shown for those with high RAB6C expression. 


\section{General discussion and clinical implications}

Patients with ER+ tumors have substantial long-term recurrence risk, despite five years of endocrine treatment [45]. Prolonged endocrine treatment has been suggested, but one question to be addressed is how to distinguish between patients that benefit from more treatment and patients with good survival anyhow.

Therefore, more specific long-term prognostic and predictive factors are needed. In this thesis, we aimed to identify factors that contribute to rule out this question.

In short, we suggest AKT2 as a long-term prognostic factor, PR as a long-term predictive factor and RAB6C as a marker for subgroup division among ER+/PRtumors.

In order to study long-term effects, we used an old data material from a study with patients being randomized between 1976 and 1990. In paper I and II, we subdivided the data into different time periods as the aim was to focus specifically on the longterm risk. The data material was too small for such a subdivision in paper III and IV without getting statistical power problem.

Our results may contribute to identification of more specific subgroups regarding treatment determination, in particular for patients with stage I disease, which is the largest group of patients and that are generally considered to have good 5-year survival. In the future, some stage I patients with ER+ tumors may be recommended prolonged or reduced treatment, depending on the status of the tumor markers PR and RAB6C. The summarized results suggest that approximately half of the patients with ER+/PR- tumors do benefit from tamoxifen (Table 8). 
Table 8 Patient distribution and survival in relation to the tumor markers PR and RAB6C

\begin{tabular}{c|l|l|}
\multicolumn{1}{|c|}{ PR+ } & \multicolumn{1}{c|}{ PR- } \\
\hline RAB6C+ & $\begin{array}{l}\text { F 40\% of the patients with } \\
\text { ER+ tumors } \\
\text { Good survival with TAM }\end{array}$ & $\begin{array}{l}\sim 15 \% \text { of the patients with } \\
\text { ER+ tumors }\end{array}$ \\
\hline RAB6C- & $\begin{array}{l}\text { Good survival without TAM } \\
\text { ER+ tumors } \\
\text { Good survival with TAM }\end{array}$ & $\begin{array}{l}\text { Poor survival without TAM } \\
\text { ER+ tumors }\end{array}$ \\
\hline
\end{tabular}

In this thesis, we investigated the clinical value of AKT2 in stage II breast cancer. In future studies, it would be interesting to include stage I patients. Another interesting aspect for future studies is to investigate the clinical behavior of AKT2 in relation to PR status.

In our studies, RAB6C was shown to provide both prognostic and predictive information about the patients' outcome, but the knowledge about the biological function of the protein is limited. Therefore, it would be interesting to perform further experimental studies in order to understand the function. 


\section{Conclusions}

AKT2 expression is associated with a lower distant recurrence rate for patients with ER+ tumors and this association remains long-term. The prognostic significance of AKT2 increases with higher estrogen receptor expression. We could not show statistical significance of AKT1 expression.

PR status determined by IHC adds predictive value to ER considering the longterm benefit from tamoxifen.

Among systemically untreated patients with ER+/PR-tumors, RAB6C independently prognosticates the risk of distant recurrence.

Patients with ER+/PR- tumors and low RAB6C expression do benefit from tamoxifen. 


\section{Acknowledgments}

Jag vill tacka alla som har bidragit till detta arbete på olika sätt, i stort och smått.

Tillsammans har ni gjort det möjligt för mig att genomföra arbetet med avhandlingen. Jag riktar ett stort tack till:

Min huvudhandledare Olle Stål och min bihandledare John Carstensen. Jag är djupt imponerad av er kunskap och av att ni är så snabba i tanken. Det är alltid intressant och roligt att diskutera med er. Jag kan inte tänka mig bättre handledare än er två och jag ser alltid fram emot våra möten i "Grodan".

Alla medförfattare till arbetena i denna avhandling och i andra forskningssamarbeten. Tack för det fina samarbetet, för att ni lär mig mycket och bidrar med så bra idéer. Speciellt tack till:

Bo Nordenskjöld för att du har enorm kunskap om bröstcancer och alltid visar stort intresse för mina arbeten. Och tack för alla humoristiska, kvicka kommentarer.

Anna Nordenskjöld för gott samarbete i arbete 2 i avhandlingen och i andra gemensamma forskningsarbeten.

Lars-Gunnar Arnesson för att det är så roligt att jobba med dig och för att jag har fått lära mig mycket om bröstcancer genom våra samarbeten över åren.

Alla nuvarande och tidigare medarbetare på Regionalt Cancercentrum Sydöst för att ni gör det roligt att gå till jobbet, trots det tunga ämnet och för att ni under perioder har avlastat mig i mitt arbete, så att jag har kunnat frigöra tid för att skriva klart avhandlingen. Jag vill också tacka mina verksamhetschefer Hans Starkhammar och Srinivas Uppugunduri för att ni har låtit mig avsätta en del av arbetstiden till doktorandstudierna.

Alla nuvarande och tidigare medarbetare i Olle Ståls forskargrupp för att ni ofta kommer med nya infallsvinklar och kloka synpunkter. Tack för att jag har fått sitta och jobba hos er $\mathrm{i}$ perioder trots att jag som statistiker är en "outsider". Det har varit så trevligt! Cynthia Veenstra, tack för din språkliga expertis. Och tack för allt labb-arbete med 
Stockholmsstudierna (Birgitta Holmlund), AKT (Gizeh Pérez-Tenorio) och RAB6C (Josefine Bostner och Tove Bekkhus).

Ämnesföreträdare Charlotta Dabrosin för att jag har fått möjlighet att genomföra min forskarutbildning inom onkologi vid Linköpings universitet.

Anand Srivastav. Thank you for inviting me to write my master thesis in your research group at Christian-Albrechts-Universität in Kiel. I had a great time in Kiel and it caught my interest in cancer research.

Alla patienter som deltar i forskningsstudier och låter forskare få tillgång till era data. Tack vare er kan cancerbehandlingen förbättras för framtida patienter.

All vårdpersonal som jobbar med cancerpatienter. Ni gör ett fantastiskt jobb med all er kunskap och goda omvårdnad!

Vänner och släktingar för alla gånger ni får mig att koppla av och bara ha det bra. Dessa stunder är så värdefulla!

Min barndomsvän Linda för allt vi har upplevt tillsammans (förtroliga samtal, skratt och tokiga resor) från att vi var små barn och in i vuxenlivet. Och tack för det fina omslaget till avhandlingen!

Min familj, som jag är så stolt över. Tack för allt vi delar i livet.

Mamma och pappa, världens bästa föräldrar och morföräldrar! Tack för tryggheten ni ger mig. Ni ställer upp så mycket och finns där för mig när jag behöver det! Tack vare er har jag klarat av flera hinder på vägen.

Min syster Maria för all uppmuntran och allt stöd under hela min doktorandtid. Men framför allt tack för all din omtanke, roliga telefonsamtal och allt annat du är och gör som storasyster och vän.

Min syster Johanna, Joel och Elliot för alla fina samtal, för att vi kan skratta och gråta ihop och för att det alltid är härligt att träffa er. Tack för att ni finns! Jag är så glad över att vara moster till fina Elliot.

Min dotter Linnéa. Min stjärna. För att du är det bästa i mitt liv. För att din betydelse inte går att beskriva med ord. $\mathcal{O}$ 


\section{References}

1. Jemal A, Bray F, Center MM, Ferlay J, Ward E, Forman D: Global cancer statistics. CA Cancer J Clin 2011, 61(2):69-90.

2. Cancer Incidence in Sweden 2014. In.: Official statistics of Sweden; December 2015: 123.

3. National Board of Health and Welfare, Statistics database http://www.socialstyrelsen.se/statistik/statistikdatabas/. 2017-10-17.

4. Schon K, Tischkowitz M: Clinical implications of germline mutations in breast cancer: TP53. Breast Cancer Res Treat 2017.

5. Edlich RF, Winters KL, Lin KY: Breast cancer and ovarian cancer genetics. J Long Term Eff Med Implants 2005, 15(5):533-545.

6. McCormack VA, dos Santos Silva I: Breast density and parenchymal patterns as markers of breast cancer risk: a meta-analysis. Cancer Epidemiol Biomarkers Prev 2006, 15(6):1159-1169.

7. Oh H, Eliassen AH, Beck AH, Rosner B, Schnitt SJ, Collins LC, Connolly JL, Montaser-Kouhsari L, Willett WC, Tamimi RM: Breast cancer risk factors in relation to estrogen receptor, progesterone receptor, insulin-like growth factor-1 receptor, and Ki67 expression in normal breast tissue. NPJ Breast Cancer 2017, 3:39.

8. Islami F, Liu Y, Jemal A, Zhou J, Weiderpass E, Colditz G, Boffetta P, Weiss M: Breastfeeding and breast cancer risk by receptor status--a systematic review and meta-analysis. Ann Oncol 2015, 26(12):2398-2407.

9. Chia KS, Reilly M, Tan CS, Lee J, Pawitan Y, Adami HO, Hall P, Mow B: Profound changes in breast cancer incidence may reflect changes into a Westernized lifestyle: a comparative population-based study in Singapore and Sweden. Int J Cancer 2005, 113(2):302-306.

10. Chlebowski RT, Anderson GL: Changing concepts: Menopausal hormone therapy and breast cancer. J Natl Cancer Inst 2012, 104(7):517-527.

11. Chlebowski RT, Anderson GL, Gass M, Lane DS, Aragaki AK, Kuller LH, Manson JE, Stefanick ML, Ockene J, Sarto GE et al: Estrogen plus progestin and breast cancer incidence and mortality in postmenopausal women. Jama 2010, 304(15):1684-1692.

12. Heiss G, Wallace R, Anderson GL, Aragaki A, Beresford SA, Brzyski R, Chlebowski RT, Gass M, LaCroix A, Manson JE et al: Health risks and benefits 3 years after stopping randomized treatment with estrogen and progestin. Jama 2008, 299(9):1036-1045.

13. Baer HJ, Tworoger SS, Hankinson SE, Willett WC: Body fatness at young ages and risk of breast cancer throughout life. Am J Epidemiol 2010, 171(11):11831194. 
14. Colditz GA, Bohlke K: Priorities for the primary prevention of breast cancer. CA Cancer J Clin 2014, 64(3):186-194.

15. Beiki O, Hall P, Ekbom A, Moradi T: Breast cancer incidence and case fatality among 4.7 million women in relation to social and ethnic background: a population-based cohort study. Breast Cancer Res 2012, 14(1):R5.

16. Breast cancer and hormone replacement therapy: collaborative reanalysis of data from 51 epidemiological studies of 52,705 women with breast cancer and 108,411 women without breast cancer. Collaborative Group on Hormonal Factors in Breast Cancer. Lancet 1997, 350(9084):1047-1059.

17. Lambe M, Wigertz A, Holmqvist M, Adolfsson J, Bardage C, Fornander T, Karlsson P, Odlind V, Persson I, Ahlgren J et al: Reductions in use of hormone replacement therapy: effects on Swedish breast cancer incidence trends only seen after several years. Breast Cancer Res Treat 2010, 121(3):679-683.

18. Jonsson $\mathrm{H}$, Johansson $\mathrm{R}$, Lenner $\mathrm{P}$ : Increased incidence of invasive breast cancer after the introduction of service screening with mammography in Sweden. Int J Cancer 2005, 117(5):842-847.

19. Lenner $\mathrm{P}$, Jonsson $\mathrm{H}$ : Excess mortality from breast cancer in relation to mammography screening in northern Sweden. J Med Screen 1997, 4(1):6-9.

20. Jonsson $H$, Bordas $P$, Wallin H, Nystrom L, Lenner P: Service screening with mammography in Northern Sweden: effects on breast cancer mortality - an update. J Med Screen 2007, 14(2):87-93.

21. Weigel MT, Dowsett M: Current and emerging biomarkers in breast cancer: prognosis and prediction. Endocr Relat Cancer 2010, 17(4):R245-262.

22. Inwald EC, Klinkhammer-Schalke M, Hofstadter F, Zeman F, Koller M, Gerstenhauer M, Ortmann O: Ki-67 is a prognostic parameter in breast cancer patients: results of a large population-based cohort of a cancer registry. Breast Cancer Res Treat 2013, 139(2):539-552.

23. Gerdes J, Schwab U, Lemke H, Stein H: Production of a mouse monoclonal antibody reactive with a human nuclear antigen associated with cell proliferation. Int J Cancer 1983, 31(1):13-20.

24. de Azambuja E, Cardoso F, de Castro G, Jr., Colozza M, Mano MS, Durbecq V, Sotiriou C, Larsimont D, Piccart-Gebhart MJ, Paesmans M: Ki-67 as prognostic marker in early breast cancer: a meta-analysis of published studies involving 12,155 patients. Br J Cancer 2007, 96(10):1504-1513.

25. Fredholm H, Eaker S, Frisell J, Holmberg L, Fredriksson I, Lindman H: Breast cancer in young women: poor survival despite intensive treatment. PLoS One 2009, 4(11):e7695.

26. Fredholm H, Magnusson K, Lindstrom LS, Garmo H, Falt SE, Lindman H, Bergh J, Holmberg L, Ponten F, Frisell J et al: Long-term outcome in young women with breast cancer: a population-based study. Breast Cancer Res Treat 2016, 160(1):131-143.

27. Eaker S, Dickman PW, Bergkvist L, Holmberg L, Uppsala/Orebro Breast Cancer $\mathrm{G}$ : Differences in management of older women influence breast cancer 
survival: results from a population-based database in Sweden. PLoS Med 2006, 3(3):e25.

28. Early Breast Cancer Trialists' Collaborative G: Effects of adjuvant tamoxifen and of cytotoxic therapy on mortality in early breast cancer. An overview of 61 randomized trials among 28,896 women. N Engl J Med 1988, 319(26):1681-1692.

29. Tamoxifen for early breast cancer: an overview of the randomised trials. Early Breast Cancer Trialists' Collaborative Group. Lancet 1998, 351(9114):1451-1467.

30. Rutqvist LE, Cedermark B, Glas U, Johansson H, Nordenskjold B, Skoog L, Somell A, Theve T, Friberg S, Askergren J: The Stockholm trial on adjuvant tamoxifen in early breast cancer. Correlation between estrogen receptor level and treatment effect. Breast Cancer Res Treat 1987, 10(3):255-266.

31. Osborne $C$, Wilson $P$, Tripathy $D$ : Oncogenes and tumor suppressor genes in breast cancer: potential diagnostic and therapeutic applications. The oncologist 2004, 9(4):361-377.

32. Piccart-Gebhart MJ, Procter M, Leyland-Jones B, Goldhirsch A, Untch M, Smith I, Gianni L, Baselga J, Bell R, Jackisch $C$ et al: Trastuzumab after adjuvant chemotherapy in HER2-positive breast cancer. N Engl J Med 2005, 353(16):1659-1672.

33. Romond EH, Perez EA, Bryant J, Suman VJ, Geyer CE, Jr., Davidson NE, Tan-Chiu E, Martino S, Paik S, Kaufman PA et al: Trastuzumab plus adjuvant chemotherapy for operable HER2-positive breast cancer. N Engl J Med 2005, 353(16):1673-1684.

34. Slamon D, Eiermann W, Robert N, Pienkowski T, Martin M, Press M, Mackey J, Glaspy J, Chan A, Pawlicki M et al: Adjuvant trastuzumab in HER2-positive breast cancer. N Engl J Med 2011, 365(14):1273-1283.

35. Gianni L, Dafni U, Gelber RD, Azambuja E, Muehlbauer S, Goldhirsch A, Untch M, Smith I, Baselga J, Jackisch C et al: Treatment with trastuzumab for 1 year after adjuvant chemotherapy in patients with HER2-positive early breast cancer: a 4-year follow-up of a randomised controlled trial. Lancet Oncol 2011, 12(3):236-244.

36. Piccart-Gebhart MJ: Adjuvant trastuzumab therapy for HER2-overexpressing breast cancer: what we know and what we still need to learn. Eur J Cancer 2006, 42(12):1715-1719.

37. Bergamaschi A, Kim YH, Wang P, Sorlie T, Hernandez-Boussard T, Lonning PE, Tibshirani R, Borresen-Dale AL, Pollack JR: Distinct patterns of DNA copy number alteration are associated with different clinicopathological features and gene-expression subtypes of breast cancer. Genes Chromosomes Cancer 2006, 45(11):1033-1040.

38. Perou CM, Sorlie T, Eisen MB, van de Rijn M, Jeffrey SS, Rees CA, Pollack JR, Ross DT, Johnsen $\mathrm{H}$, Akslen LA et al: Molecular portraits of human breast tumours. Nature 2000, 406(6797):747-752. 
39. Sorlie T, Perou CM, Tibshirani R, Aas T, Geisler S, Johnsen H, Hastie T, Eisen $M B$, van de Rijn $M$, Jeffrey SS et al: Gene expression patterns of breast carcinomas distinguish tumor subclasses with clinical implications. Proc Natl Acad Sci U S A 2001, 98(19):10869-10874.

40. Goldhirsch A, Winer EP, Coates AS, Gelber RD, Piccart-Gebhart M, Thurlimann $B$, Senn HJ, Panel m: Personalizing the treatment of women with early breast cancer: highlights of the St Gallen International Expert Consensus on the Primary Therapy of Early Breast Cancer 2013. Ann Oncol 2013, 24(9):22062223.

41. Sant M, Chirlaque Lopez MD, Agresti R, Sanchez Perez MJ, Holleczek B, BielskaLasota M, Dimitrova N, Innos K, Katalinic A, Langseth $\mathrm{H}$ et al: Survival of women with cancers of breast and genital organs in Europe 1999-2007: Results of the EUROCARE-5 study. Eur J Cancer 2015, 51(15):2191-2205.

42. Coleman MP, Forman D, Bryant H, Butler J, Rachet B, Maringe C, Nur U, Tracey $\mathrm{E}$, Coory M, Hatcher J et al: Cancer survival in Australia, Canada, Denmark, Norway, Sweden, and the UK, 1995-2007 (the International Cancer Benchmarking Partnership): an analysis of population-based cancer registry data. Lancet 2011, 377(9760):127-138.

43. Saphner T, Tormey DC, Gray R: Annual hazard rates of recurrence for breast cancer after primary therapy. J Clin Oncol 1996, 14(10):2738-2746.

44. Early Breast Cancer Trialists' Collaborative G: Effects of chemotherapy and hormonal therapy for early breast cancer on recurrence and 15-year survival: an overview of the randomised trials. Lancet 2005, 365(9472):1687-1717.

45. Pan H, Gray R, Braybrooke J, Davies C, Taylor C, McGale P, Peto R, Pritchard KI, Bergh J, Dowsett M et al: 20-Year Risks of Breast-Cancer Recurrence after Stopping Endocrine Therapy at 5 Years. N Engl J Med 2017, 377(19):18361846.

46. Sestak I, Cuzick J: Markers for the identification of late breast cancer recurrence. Breast cancer research : BCR 2015, 17:10.

47. Fisher B, Anderson S, Bryant J, Margolese RG, Deutsch M, Fisher ER, Jeong JH, Wolmark N: Twenty-year follow-up of a randomized trial comparing total mastectomy, lumpectomy, and lumpectomy plus irradiation for the treatment of invasive breast cancer. N Engl J Med 2002, 347(16):1233-1241.

48. Litiere S, Werutsky G, Fentiman IS, Rutgers E, Christiaens MR, Van Limbergen $\mathrm{E}$, Baaijens $\mathrm{MH}$, Bogaerts J, Bartelink $\mathrm{H}$ : Breast conserving therapy versus mastectomy for stage I-II breast cancer: 20 year follow-up of the EORTC 10801 phase 3 randomised trial. Lancet Oncol 2012, 13(4):412-419.

49. Veronesi U, Cascinelli N, Mariani L, Greco M, Saccozzi R, Luini A, Aguilar M, Marubini E: Twenty-year follow-up of a randomized study comparing breastconserving surgery with radical mastectomy for early breast cancer. $N$ Engl J Med 2002, 347(16):1227-1232.

50. Lotfi-Jam K, Carey M, Jefford M, Schofield P, Charleson C, Aranda S: Nonpharmacologic strategies for managing common chemotherapy adverse effects: a systematic review. J Clin Oncol 2008, 26(34):5618-5629. 
51. Gupta P, Sturdee DW, Palin SL, Majumder K, Fear R, Marshall T, Paterson I: Menopausal symptoms in women treated for breast cancer: the prevalence and severity of symptoms and their perceived effects on quality of life. Climacteric 2006, 9(1):49-58.

52. Johansson S, Svensson H, Denekamp J: Dose response and latency for radiation-induced fibrosis, edema, and neuropathy in breast cancer patients. International journal of radiation oncology, biology, physics 2002, 52(5):12071219.

53. Segaert S, Van Cutsem E: Clinical signs, pathophysiology and management of skin toxicity during therapy with epidermal growth factor receptor inhibitors. Ann Oncol 2005, 16(9):1425-1433.

54. van de Vijver MJ, He YD, van't Veer LJ, Dai H, Hart AA, Voskuil DW, Schreiber GJ, Peterse JL, Roberts C, Marton MJ et al: A gene-expression signature as a predictor of survival in breast cancer. The New England journal of medicine 2002, 347(25):1999-2009.

55. Xin L, Liu YH, Martin TA, Jiang WG: The Era of Multigene Panels Comes? The Clinical Utility of Oncotype DX and MammaPrint. World J Oncol 2017, 8(2):3440.

56. Harris LN, Ismaila N, McShane LM, Hayes DF: Use of Biomarkers to Guide Decisions on Adjuvant Systemic Therapy for Women With Early-Stage Invasive Breast Cancer: American Society of Clinical Oncology Clinical Practice Guideline Summary. J Oncol Pract 2016, 12(4):384-389.

57. Coates AS, Winer EP, Goldhirsch A, Gelber RD, Gnant M, Piccart-Gebhart M, Thurlimann B, Senn HJ, Panel M: Tailoring therapies--improving the management of early breast cancer: St Gallen International Expert Consensus on the Primary Therapy of Early Breast Cancer 2015. Ann Oncol 2015, 26(8):1533-1546.

58. Ohnstad HO, Borgen E, Falk RS, Lien TG, Aaserud M, Sveli MAT, Kyte JA, Kristensen VN, Geitvik GA, Schlichting E et al: Prognostic value of PAM50 and risk of recurrence score in patients with early-stage breast cancer with longterm follow-up. Breast Cancer Res 2017, 19(1):120.

59. Paik S, Shak S, Tang G, Kim C, Baker J, Cronin M, Baehner FL, Walker MG, Watson D, Park T et al: A multigene assay to predict recurrence of tamoxifentreated, node-negative breast cancer. N Engl J Med 2004, 351(27):2817-2826.

60. Zhang Y, Schnabel CA, Schroeder BE, Jerevall PL, Jankowitz RC, Fornander T, Stal O, Brufsky AM, Sgroi D, Erlander MG: Breast cancer index identifies earlystage estrogen receptor-positive breast cancer patients at risk for early- and late-distant recurrence. Clin Cancer Res 2013, 19(15):4196-4205.

61. Dowsett M, Sestak I, Lopez-Knowles E, Sidhu K, Dunbier AK, Cowens JW, Ferree $\mathrm{S}$, Storhoff J, Schaper C, Cuzick J: Comparison of PAM50 risk of recurrence score with oncotype DX and IHC4 for predicting risk of distant recurrence after endocrine therapy. Journal of clinical oncology : official journal of the American Society of Clinical Oncology 2013, 31(22):2783-2790. 
62. Dubsky P, Brase JC, Jakesz R, Rudas M, Singer CF, Greil R, Dietze O, Luisser I, Klug $E$, Sedivy $R$ et al: The EndoPredict score provides prognostic information on late distant metastases in ER+/HER2- breast cancer patients. British journal of cancer 2013, 109(12):2959-2964.

63. Galanina N, Bossuyt V, Harris LN: Molecular predictors of response to therapy for breast cancer. Cancer J 2011, 17(2):96-103.

64. Hanahan D, Weinberg RA: Hallmarks of cancer: the next generation. Cell 2011, 144(5):646-674.

65. Hanahan D, Weinberg RA: The hallmarks of cancer. Cell 2000, 100(1):57-70.

66. Esteller M: Epigenetics in cancer. N Engl J Med 2008, 358(11):1148-1159.

67. Vogelstein B, Lane D, Levine AJ: Surfing the p53 network. Nature 2000, 408(6810):307-310.

68. Pucci B, Kasten M, Giordano A: Cell cycle and apoptosis. Neoplasia 2000, 2(4):291-299.

69. Young J, Menetrey J, Goud B: RAB6C is a retrogene that encodes a centrosomal protein involved in cell cycle progression. J Mol Biol 2010, 397(1):69-88.

70. Gan L, Zuo G, Wang T, Min J, Wang Y, Wang Y, Lv G: Expression of WTH3 in breast cancer tissue and the effects on the biological behavior of breast cancer cells. Experimental and therapeutic medicine 2015, 10(1):154-158.

71. Gross JM, Yee D: How does the estrogen receptor work? Breast Cancer Res 2002, 4(2):62-64.

72. Sever R, Glass CK: Signaling by nuclear receptors. Cold Spring Harb Perspect Biol 2013, 5(3):a016709.

73. Yasar P, Ayaz G, User SD, Gupur G, Muyan M: Molecular mechanism of estrogen-estrogen receptor signaling. Reprod Med Biol 2017, 16(1):4-20.

74. Marino M, Galluzzo P, Ascenzi P: Estrogen signaling multiple pathways to impact gene transcription. Curr Genomics 2006, 7(8):497-508.

75. Tanos $T$, Rojo L, Echeverria P, Brisken C: ER and PR signaling nodes during mammary gland development. Breast Cancer Res 2012, 14(4):210.

76. Welboren WJ, Sweep FC, Span PN, Stunnenberg HG: Genomic actions of estrogen receptor alpha: what are the targets and how are they regulated? Endocr Relat Cancer 2009, 16(4):1073-1089.

77. Petz LN, Ziegler YS, Loven MA, Nardulli AM: Estrogen receptor alpha and activating protein-1 mediate estrogen responsiveness of the progesterone receptor gene in MCF-7 breast cancer cells. Endocrinology 2002, 143(12):4583-4591.

78. Levin ER: Integration of the extranuclear and nuclear actions of estrogen. Mol Endocrinol 2005, 19(8):1951-1959.

79. Grann VR, Troxel AB, Zojwalla NJ, Jacobson JS, Hershman D, Neugut AI: Hormone receptor status and survival in a population-based cohort of patients with breast carcinoma. Cancer 2005, 103(11):2241-2251. 
80. Hefti MM, Hu R, Knoblauch NW, Collins LC, Haibe-Kains B, Tamimi RM, Beck $\mathrm{AH}$ : Estrogen receptor negative/progesterone receptor positive breast cancer is not a reproducible subtype. Breast Cancer Res 2013, 15(4):R68.

81. Arpino G, Weiss H, Lee AV, Schiff R, De Placido S, Osborne CK, Elledge RM: Estrogen receptor-positive, progesterone receptor-negative breast cancer: association with growth factor receptor expression and tamoxifen resistance. J Natl Cancer Inst 2005, 97(17):1254-1261.

82. Cui X, Schiff R, Arpino G, Osborne CK, Lee AV: Biology of progesterone receptor loss in breast cancer and its implications for endocrine therapy. $J$ Clin Oncol 2005, 23(30):7721-7735.

83. Cancello G, Maisonneuve P, Rotmensz N, Viale G, Mastropasqua MG, Pruneri G, Montagna E, lorfida M, Mazza M, Balduzzi A et al: Progesterone receptor loss identifies Luminal B breast cancer subgroups at higher risk of relapse. Ann Oncol 2013, 24(3):661-668.

84. Huang HJ, Neven $P$, Drijkoningen $M$, Paridaens $R$, Wildiers $H$, Van Limbergen $E$, Berteloot P, Amant F, Christiaens MR, Vergote I: Association between HER$2 /$ neu and the progesterone receptor in oestrogen-dependent breast cancer is age-related. Breast Cancer Res Treat 2005, 91(1):81-87.

85. Taucher S, Rudas M, Mader RM, Gnant M, Dubsky P, Bachleitner T, Roka S, Fitzal F, Kandioler D, Sporn E et al: Do we need HER-2/neu testing for all patients with primary breast carcinoma? Cancer 2003, 98(12):2547-2553.

86. Stal O, Brisfors A, Carstensen J, Ferraud L, Hatschek T, Nordenskjold B: Interrelations between cellular DNA content, S-phase fraction, hormone receptor status and age in primary breast cancer. A series of 1,342 consecutively detected tumors. South-East Sweden Breast Cancer Group. Acta Oncol 1992, 31(3):283-292.

87. Fallahpour S, Navaneelan T, De P, Borgo A: Breast cancer survival by molecular subtype: a population-based analysis of cancer registry data. CMAJ Open 2017, 5(3):E734-E739.

88. Thakkar JP, Mehta DG: A review of an unfavorable subset of breast cancer: estrogen receptor positive progesterone receptor negative. The oncologist 2011, 16(3):276-285.

89. Miller TW, Rexer BN, Garrett JT, Arteaga CL: Mutations in the phosphatidylinositol 3-kinase pathway: role in tumor progression and therapeutic implications in breast cancer. Breast Cancer Res 2011, 13(6):224.

90. Campbell RA, Bhat-Nakshatri P, Patel NM, Constantinidou D, Ali S, Nakshatri H: Phosphatidylinositol 3-kinase/AKT-mediated activation of estrogen receptor alpha: a new model for anti-estrogen resistance. J Biol Chem 2001, 276(13):9817-9824.

91. Nicholson KM, Anderson NG: The protein kinase B/Akt signalling pathway in human malignancy. Cell Signal 2002, 14(5):381-395.

92. Alessi DR, James SR, Downes CP, Holmes AB, Gaffney PR, Reese CB, Cohen P: Characterization of a 3-phosphoinositide-dependent protein kinase which 
phosphorylates and activates protein kinase Balpha. Curr Biol 1997, 7(4):261269.

93. Sarbassov DD, Guertin DA, Ali SM, Sabatini DM: Phosphorylation and regulation of Akt/PKB by the rictor-mTOR complex. Science 2005, 307(5712):1098-1101.

94. Gonzalez E, McGraw TE: The Akt kinases: isoform specificity in metabolism and cancer. Cell Cycle 2009, 8(16):2502-2508.

95. Staal SP, Hartley JW, Rowe WP: Isolation of transforming murine leukemia viruses from mice with a high incidence of spontaneous lymphoma. Proc Natl Acad Sci U S A 1977, 74(7):3065-3067.

96. Staal SP: Molecular cloning of the akt oncogene and its human homologues AKT1 and AKT2: amplification of AKT1 in a primary human gastric adenocarcinoma. Proc Natl Acad Sci U S A 1987, 84(14):5034-5037.

97. Brodbeck D, Cron $P$, Hemmings BA: A human protein kinase Bgamma with regulatory phosphorylation sites in the activation loop and in the C-terminal hydrophobic domain. J Biol Chem 1999, 274(14):9133-9136.

98. Pérez-Tenorio G, Karlsson E, Stål O: Clinical value of isoform-specific detection and targeting of AKT1, AKT2 and AKT3 in breast cancer. Breast Cancer Management 2014, 3(5):409-421.

99. Dillon RL, Muller WJ: Distinct biological roles for the akt family in mammary tumor progression. Cancer Res 2010, 70(11):4260-4264.

100. Dillon RL, Marcotte R, Hennessy BT, Woodgett JR, Mills GB, Muller WJ: Akt1 and akt2 play distinct roles in the initiation and metastatic phases of mammary tumor progression. Cancer Res 2009, 69(12):5057-5064.

101. Banerji S, Cibulskis K, Rangel-Escareno C, Brown KK, Carter SL, Frederick AM, Lawrence MS, Sivachenko AY, Sougnez C, Zou L et al: Sequence analysis of mutations and translocations across breast cancer subtypes. Nature 2012, 486(7403):405-409.

102. Polyak K, Metzger Filho O: SnapShot: breast cancer. Cancer Cell 2012, 22(4):562-562 e561.

103. Pereira-Leal JB, Seabra MC: Evolution of the Rab family of small GTP-binding proteins. J Mol Biol 2001, 313(4):889-901.

104. Tian K, Wang Y, Huang Y, Sun B, Li Y, Xu H: Methylation of WTH3, a possible drug resistant gene, inhibits $\mathrm{p} 53$ regulated expression. BMC cancer 2008, 8:327.

105. Tian $\mathrm{K}$, Wang $\mathrm{Y}, \mathrm{Xu} \mathrm{H}$ : WTH3 is a direct target of the p53 protein. Br J Cancer 2007, 96(10):1579-1586.

106. National Center for Biotechnology Information, https://www.ncbi.nIm.nih.gov/. 2014-10-15.

107. Khoshnoud MR, Lofdahl B, Fohlin H, Fornander T, Stal O, Skoog L, Bergh J, Nordenskjold B: Immunohistochemistry compared to cytosol assays for determination of estrogen receptor and prediction of the long-term effect of adjuvant tamoxifen. Breast Cancer Res Treat 2011, 126(2):421-430. 
108. Rastelli F, Crispino S: Factors predictive of response to hormone therapy in breast cancer. Tumori 2008, 94(3):370-383.

109. Wrange O, Nordenskjold B, Silfversward C, Granberg PO, Gustafsson JA: Isoelectric focusing of estradiol receptor protein from human mammary carcinoma - a comparison to sucrose gradient analysis. Eur J Cancer 1976, 12(9):695-700.

110. Wrange O, Nordenskjold B, Gustafsson JA: Cytosol estradiol receptor in human mammary carcinoma: an assay based on isoelectric focusing in polyacrylamide gel. Analytical biochemistry 1978, 85(2):461-475.

111. Gustafsson JA, Gustafsson SA, Nordenskjold B, Okret S, Silfversward C, Wrange $\mathrm{O}$ : Estradiol receptor analysis in human breast cancer tissue by isoelectric focusing in polyacrylamide gel. Cancer Res 1978, 38(11 Pt 2):4225-4228.

112. Khoshnoud MR, Fornander T, Johansson H, Rutqvist LE: Long-term pattern of disease recurrence among patients with early-stage breast cancer according to estrogen receptor status and use of adjuvant tamoxifen. Breast Cancer Res Treat 2008, 107(1):71-78.

113. Ferno M, Borg A, Norgren A: A comparison of two steroid receptor assays in breast cancer: dextran coated charcoal and isoelectric focusing. Anticancer Res 1983, 3(4):243-246.

114. Ferno M, Borg A, Sellberg G: Enzyme immuno assay of the estrogen receptor in breast cancer biopsy samples. A comparison with isoelectric focusing. Acta Radiol Oncol 1986, 25(3):171-175.

115. Brookes ST, Whitley E, Peters TJ, Mulheran PA, Egger M, Davey Smith G: Subgroup analyses in randomised controlled trials: quantifying the risks of false-positives and false-negatives. Health Technol Assess 2001, 5(33):1-56.

116. Brookes ST, Whitely E, Egger M, Smith GD, Mulheran PA, Peters TJ: Subgroup analyses in randomized trials: risks of subgroup-specific analyses; power and sample size for the interaction test. J Clin Epidemiol 2004, 57(3):229-236.

117. DeMets DL: Statistical issues in interpreting clinical trials. Journal of internal medicine 2004, 255(5):529-537.

118. Dijkman B, Kooistra B, Bhandari M, Evidence-Based Surgery Working G: How to work with a subgroup analysis. Can J Surg 2009, 52(6):515-522.

119. Kaplan E, Meier P: Nonparametric estimation from incomplete observations. Journal of the American Statistical Association 1958(53):457-481.

120. Cox DR: Regression Models and Life-Tables. Journal of the Royal Statistical Society Series B (Methodological) 1972, 34(2):187-220.

121. Spruance SL, Reid JE, Grace M, Samore M: Hazard ratio in clinical trials. Antimicrobial agents and chemotherapy 2004, 48(8):2787-2792.

122. Kirkwood B, Sterne J: Medical Statistics, 2nd edn. USA: Blackwell Publishing company; 1988.

123. Bonetti M, Gelber RD: A graphical method to assess treatment-covariate interactions using the Cox model on subsets of the data. Stat Med 2000, 19(19):2595-2609. 
124. Royston P, Sauerbrei W: A new approach to modelling interactions between treatment and continuous covariates in clinical trials by using fractional polynomials. Stat Med 2004, 23(16):2509-2525.

125. Royston $P$, Sauerbrei W: Interactions between treatment and continuous covariates: a step toward individualizing therapy. J Clin Oncol 2008, 26(9):1397-1399.

126. Zhang Y, Martens JW, Yu JX, Jiang J, Sieuwerts AM, Smid M, Klijn JG, Wang Y, Foekens JA: Copy number alterations that predict metastatic capability of human breast cancer. Cancer Res 2009, 69(9):3795-3801.

127. Tian K, Jurukovski V, Wang XP, Kaplan $\mathrm{MH}, \mathrm{Xu} \mathrm{H}$ : Epigenetic regulation of WTH3 in primary and cultured drug-resistant breast cancer cells. Cancer Res 2005, 65(21):10024-10031.

128. Tian K, Jurukovski V, Yuan L, Shan J, Xu H: WTH3, which encodes a small G protein, is differentially regulated in multidrug-resistant and sensitive MCF7 cells. Cancer Res 2005, 65(16):7421-7428.

129. Shan J, Mason JM, Yuan L, Barcia M, Porti D, Calabro A, Budman D, Vinciguerra $\mathrm{V}, \mathrm{Xu} \mathrm{H}$ : Rab6c, a new member of the rab gene family, is involved in drug resistance in MCF7/AdrR cells. Gene 2000, 257(1):67-75.

130. Shan J, Yuan L, Budman DR, Xu HP: WTH3, a new member of the Rab6 gene family, and multidrug resistance. Biochim Biophys Acta 2002, 1589(2):112123.

131. Soerjomataram I, Louwman MW, Ribot JG, Roukema JA, Coebergh JW: An overview of prognostic factors for long-term survivors of breast cancer. Breast Cancer Res Treat 2008, 107(3):309-330.

132. Olivotto IA, Truong PT, Speers CH, Bernstein V, Allan SJ, Kelly SJ, Lesperance $\mathrm{ML}$ : Time to stop progesterone receptor testing in breast cancer management. J Clin Oncol 2004, 22(9):1769-1770.

133. Mohammed H, Russell IA, Stark R, Rueda OM, Hickey TE, Tarulli GA, Serandour AA, Birrell SN, Bruna A, Saadi A et al: Progesterone receptor modulates ERalpha action in breast cancer. Nature 2015, 523(7560):313-317.

134. Early Breast Cancer Trialists' Collaborative G, Davies C, Godwin J, Gray R, Clarke M, Cutter D, Darby S, McGale P, Pan HC, Taylor C et al: Relevance of breast cancer hormone receptors and other factors to the efficacy of adjuvant tamoxifen: patient-level meta-analysis of randomised trials. Lancet 2011, 378(9793):771-784.

135. Bhat S, Kabekkodu SP, Jayaprakash C, Radhakrishnan R, Ray S, Satyamoorthy K: Gene promoter-associated CpG island hypermethylation in squamous cell carcinoma of the tongue. Virchows Arch 2017, 470(4):445-454.

136. Bhat S, Kabekkodu SP, Varghese VK, Chakrabarty S, Mallya SP, Rotti H, Pandey D, Kushtagi P, Satyamoorthy K: Aberrant gene-specific DNA methylation signature analysis in cervical cancer. Tumour biology : the journal of the International Society for Oncodevelopmental Biology and Medicine 2017, 39(3):1010428317694573. 


\section{Papers}

The papers associated with this thesis have been removed for copyright reasons. For more details about these see:

http://urn.kb.se/resolve?urn=urn:nbn:se:liu:diva-145398 